\title{
Chapter 3 \\ Present Day Carbon Dioxide Fluxes in the Coastal Ocean and Possible Feedbacks Under Global Change
}

\author{
Alberto V. Borges
}

\begin{abstract}
The present day contemporary $\mathrm{CO}_{2}$ fluxes in shelf seas could be significant for the global carbon cycle, since available estimates converge to a sink

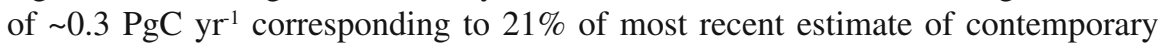

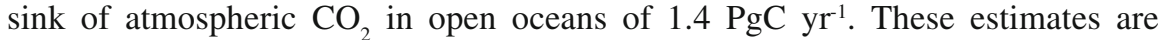
prone to large uncertainty mainly due to inadequate representation of the spatial variability and need to be improved based on more data, requiring a concerted global observational effort. The potential feedbacks on increasing atmospheric $\mathrm{CO}_{2}$ from changes in carbon flows in the coastal ocean could be disproportionately higher than in the open ocean. The changes in carbon flows and related potential feedbacks in the coastal ocean could be driven by 3 main processes: i) changes in coastal physics; ii) changes in land-used, waste water inputs, agricultural fertilizers and changes in hydrological cycle; iii) changes in seawater carbonate chemistry (ocean acidification). These potential feedbacks remain largely unquantified due to a poor understanding of the underlying mechanisms, or lack of modelling to quantify them. Based on reported evaluations and back of the envelop calculations, it is suggested that changes of biological activity due the increased nutrient delivery by rivers would provide by 2100 a negative feedback on increasing atmospheric $\mathrm{CO}_{2}$ of the order of magnitude of the present day sink for atmospheric $\mathrm{CO}_{2}$. This negative feedback on increasing atmospheric $\mathrm{CO}_{2}$ would be one order of magnitude higher than negative feedback due to the decrease of either pelagic or benthic calcification related to ocean acidification, and than the negative feedback related to dissolution of $\mathrm{CaCO}_{3}$ in sediments. The increase of export production could also provide a significant feedback to increasing atmospheric $\mathrm{CO}_{2}$, although based on the conclusions from a single perturbation experiment. Feedbacks on increasing atmospheric $\mathrm{CO}_{2}$ due to effects of $\mathrm{C}$ cycling in continental shelf seas related to changes in circulation or stratification could be important but remain to be quantified.
\end{abstract}

\footnotetext{
A.V. Borges $(\bowtie)$

Chemical Oceanography Unit, University of Liège, Belgium

e-mail: alberto.borges@ulg.ac.be
} 
Keywords Carbon dioxide fluxes • Green house gases • Global change • Coastal ocean $\bullet$ Coastal environments $\bullet$ Feedbacks $\bullet$ Land use $\bullet$ Waste water inputs $\bullet$ Agricultural fertilizers $\bullet$ Hydrological cycle $\bullet$ Atmospheric deposition $\bullet$ Ocean acidification

Warming of the climate system is unequivocal based on observational evidence from all continents and most oceans (increases in global average air and ocean temperatures, melting of snow and ice, and increasing global average sea level) (IPCC 2007a). The observed increase in global average temperatures since the industrial revolution is very likely due to increasing concentrations in the atmosphere of anthropogenic green house gases (GHG). Global GHG emissions are expected to continue to grow over the next few decades, and warming and climate change in the near and long term will have a variety of negative impacts such as: changes in terrestrial and marine ecosystems (increased risk of species extinction, changes in ecosystem structure and function, loss of biodiversity, loss of ecosystem goods and services,...), changes in crop productivity, increasing risks on coasts (coastal erosion, floods,...), increasing exposure to extreme weather events (heat waves, heavy precipitation events, incidence of extreme high sea level,...), effects on health status of millions of people (increases in malnutrition, diseases, injury due to extreme weather events,...), exacerbate current stresses on water resources,... (IPCC 2007b).

Carbon dioxide $\left(\mathrm{CO}_{2}\right)$ is the most important anthropogenic GHG accounting for $77 \%$ of total anthropogenic GHG emissions in 2004 (IPCC 2007a). For the 2000-2006 period, 9.1 $\mathrm{PgC}_{\text {year }}{ }^{-1}\left(\mathrm{PgC}=10^{15} \mathrm{gC}\right)$ of $\mathrm{CO}_{2}$ were emitted to the atmosphere mainly from fossil fuel combustion and cement production (7.6 $\left.\mathrm{PgC}_{\mathrm{gear}}{ }^{-1}\right)$ and land use change (1.5 $\left.\mathrm{PgC}_{\text {year }}{ }^{-1}\right)$. About 4.1 $\mathrm{PgC}_{\text {year }}{ }^{-1}$ accumulated in the atmosphere, the land biosphere is supposed to have absorbed $2.8 \mathrm{PgC} \mathrm{year}^{-1}$, and the oceans have absorbed the remaining 2.2 $\mathrm{PgC} \mathrm{year}^{-1}$ (Canadell et al. 2007). Hence, oceans are a major component of the global $\mathrm{CO}_{2}$ cycle. However, the oceans are also vulnerable to climate change with potential changes in their capacity to absorb anthropogenic $\mathrm{CO}_{2}$. These vulnerabilities include surface warming and related changes in circulation that will impact directly the chemical and physical oceanic $\mathrm{CO}_{2}$ pumps. Changes in ocean physics are also expected to modify the vertical inputs of inorganic nutrients and light availability (increasing stratification), hence, affecting primary production and ecosystem structure, and modifying the biological $\mathrm{CO}_{2}$ pump. The latter is also expected to respond to changes of seawater carbonate chemistry (ocean acidification) that could modify the rates and fates of primary production and calcification of numerous organisms.

Coastal environments only represent $7 \%$ of the total oceanic surface area, however, they are biogeochemically more dynamic, and probably more vulnerable to climate changes than the open ocean. Whatever the responses of the open ocean to climate changes, they will propagate on the coastal ocean. Superimposed on this "background open oceanic forcing", the coastal ocean will also respond to changes of fluxes from the land biosphere through rivers, ground waters and atmospheric deposition of major biogeochemical elements (carbon, nitrogen, phosphorous, silica) in organic and inorganic forms. Physical settings specific to the coastal ocean (coastal 
upwelling, sea-ice,...) are also expected to respond to climate change probably leading to unique and local changes in carbon cycling. Finally, due to the shallowness of the coastal ocean, the benthic compartment will respond to changes of carbon cycling in surface waters on much shorter time scales than in the open ocean.

This chapter focuses on $\mathrm{CO}_{2}$ cycling in the coastal ocean, briefly summarizing the current knowledge on the present day fluxes, and focussing more in depth on the possible evolution and feedbacks under global change.

\subsection{Present Day Carbon Dioxide Fluxes in the Coastal Ocean}

Continental shelf seas receive massive inputs of organic matter and nutrients from land, exchange large amounts of matter and energy with the open ocean across continental slopes and constitute one of the most biogeochemically active areas of the biosphere. The coastal ocean hosts between $\sim 15 \%$ and $\sim 30 \%$ of oceanic primary production and $\sim 80 \%$ of oceanic organic matter burial (e.g. Gattuso et al. 1998a). It also hosts most of the benthic oceanic calcium carbonate $\left(\mathrm{CaCO}_{3}\right)$ production, $\sim 20 \%$ of surface pelagic oceanic $\mathrm{CaCO}_{3}$ stock (Balch et al. 2005), and $\sim 50 \%$ of oceanic $\mathrm{CaCO}_{3}$ deposition (Gattuso et al. 1998a). Hence, carbon (C) flows in the coastal ocean are disproportionately high in comparison with its surface area $(\sim 7 \%$ of total oceanic surface area). Intense air-water carbon dioxide $\left(\mathrm{CO}_{2}\right)$ exchanges can then be expected in the coastal ocean and could be significant for $\mathrm{CO}_{2}$ flux budgets at regional (Frankignoulle and Borges 2001; Borges et al. 2006) and global scales (Table 3.1).

The contemporary flux of $\mathrm{CO}_{2}$ between the coastal ocean and the atmosphere has been evaluated by several authors based on the global extrapolation of a flux value from a single shelf sea or from the compilation of literature data in several shelf seas (Table 3.1). The most recent evaluations converge towards a sink of atmospheric $\mathrm{CO}_{2}$ of about $0.3 \mathrm{PgC}$ year-1. This $\mathrm{CO}_{2}$ sink would be highly significant, corresponding to $21 \%$ of the most recent estimate of contemporary sink of atmospheric $\mathrm{CO}_{2}$ in open oceans of 1.4 PgC year-1 (Takahashi et al. 2009).

Yet, these estimates based on literature compilations suffer from several caveats, one of the most important being the lack of data to adequately cover the full spatial extent of the coastal ocean and the diversity of biogeochemical $\mathrm{C}$ cycling related to extremely contrasted physical and biogeochemical settings. Indeed, the distribution of $\mathrm{CO}_{2}$ flux data in shelf seas reported in literature is biased towards the mid-latitudes of the Northern Hemisphere. Data are lacking in large portions of the coastal ocean such as the Russian Arctic coast, the Eastern South America coast, the Eastern Africa coast, large sections of the Western Africa coast and large sections of the Antarctic coast.

Further, due to the high dynamic range of seasonal and spatial variations of the partial pressure of $\mathrm{CO}_{2}\left(\mathrm{pCO}_{2}\right)$ in coastal environments (Fig. 3.1), reported air-sea $\mathrm{CO}_{2}$ fluxes can be biased by inadequate spatial or temporal coverage. For instance, in the Southern Bight of the North Sea where Thomas et al. (2004) reported a 
Table 3.1 Reported estimates of the sink for atmospheric $\mathrm{CO}_{2}$ in the coastal ocean (excluding near-shore environments)

\begin{tabular}{|c|c|c|}
\hline $\begin{array}{l}\mathrm{CO}_{2} \text { sink } \\
\left(\mathrm{PgC}_{\text {year }}{ }^{-1}\right)\end{array}$ & Reference & Comment \\
\hline $\begin{array}{ll}-1.0 \\
\end{array}$ & Tsunogai et al. (1999) & $\begin{array}{l}\text { Based on the global extrapolation of the average } \\
\text { air-sea } \mathrm{CO}_{2} \text { flux in the East China Sea } \\
\text { computed from five cruises (February 1993, } \\
\text { October 1993, August 1993, November } \\
1995 \text { and September 1996). The annual } \\
\text { air-sea } \mathrm{CO}_{2} \text { flux of Tsunogai et al. (1999) } \\
\left(2.9 \text { molC m}^{-2} \text { year }{ }^{-1}\right) \text { has been revised to } \\
\text { a lower value }\left(1.2 \text { molC m}^{-2} \text { year }{ }^{-1} \text {, Wang }\right. \\
\text { et al. 2000) based on a better coverage of } \\
\text { the seasonal cycle and use of gas transfer } \\
\text { velocities computed from wind speed rather } \\
\text { than a constant value. }\end{array}$ \\
\hline-0.40 & Thomas et al. (2004) & $\begin{array}{l}\text { Based on the global extrapolation of the average } \\
\text { air-sea } \mathrm{CO}_{2} \text { flux in the North Sea }(1.4 \text { molC } \\
\left.\mathrm{m}^{-2} \text { year }{ }^{-1}\right) \text { computed from four cruises } \\
\text { (September 2001, November 2001, February } \\
\text { 2002, May 2002). }\end{array}$ \\
\hline-0.37 & Borges (2005) & $\begin{array}{l}\text { Based on the compilation of annually integrated } \\
\text { air-sea } \mathrm{CO}_{2} \text { fluxes in } 15 \text { shelf seas as reported } \\
\text { in literature using partial pressure of } \mathrm{CO}_{2} \\
\left(\mathrm{pCO}_{2}\right) \text { measurements, scaled by latitudinal } \\
\text { bands of } 30^{\circ} \text { based on surface areas reported } \\
\text { by Walsh }(1988) \text {. Surface areas between } 30^{\circ} \mathrm{S} \\
\text { and } 30^{\circ} \mathrm{N} \text { are under-estimated. }\end{array}$ \\
\hline-0.45 & Borges et al. (2005) & $\begin{array}{l}\text { Based on the compilation of annually integrated } \\
\text { air-sea } \mathrm{CO}_{2} \text { fluxes in } 17 \text { shelf seas as reported } \\
\text { in literature using } \mathrm{pCO}_{2} \text { measurements, scaled } \\
\text { by latitudinal bands of } 30^{\circ} \text { based on surface } \\
\text { areas reported by Walsh }(1988) \text {. Air-sea } \mathrm{CO}_{2} \\
\text { fluxes were recomputed to an uniform gas } \\
\text { transfer velocity parameterization. Surface areas } \\
\text { between } 30^{\circ} \mathrm{S} \text { and } 30^{\circ} \mathrm{N} \text { are under-estimated. }\end{array}$ \\
\hline-0.22 & Cai et al. (2006) & $\begin{array}{l}\text { Based on the compilation of air-sea } \mathrm{CO}_{2} \text { fluxes in } \\
29 \text { shelf seas, scaled by } 7 \text { shelf provinces using } \\
\text { classification and surface areas reported by } \\
\text { Walsh (1988). Not all the air-sea } \mathrm{CO}_{2} \text { fluxes } \\
\text { have a full annual coverage, and some of the } \\
\text { fluxes are derived from C mass balance and } \\
\text { not } \mathrm{pCO}_{2} \text { measurements. }\end{array}$ \\
\hline-0.33 to -0.35 & Chen and Borges (2009) & $\begin{array}{l}\text { Based on the compilation of air-sea } \mathrm{CO}_{2} \text { fluxes } \\
\text { in } 58 \text { shelf seas, scaled using a global average } \\
\text { or by shelf provinces using classification } \\
\text { and surface areas reported by Jahnke (2009). } \\
\text { Not all the air-sea } \mathrm{CO}_{2} \text { fluxes have a full } \\
\text { annual coverage and some of the fluxes are } \\
\text { derived from } \mathrm{C} \text { mass balance and not } \mathrm{pCO}_{2} \\
\text { measurements. }\end{array}$ \\
\hline
\end{tabular}




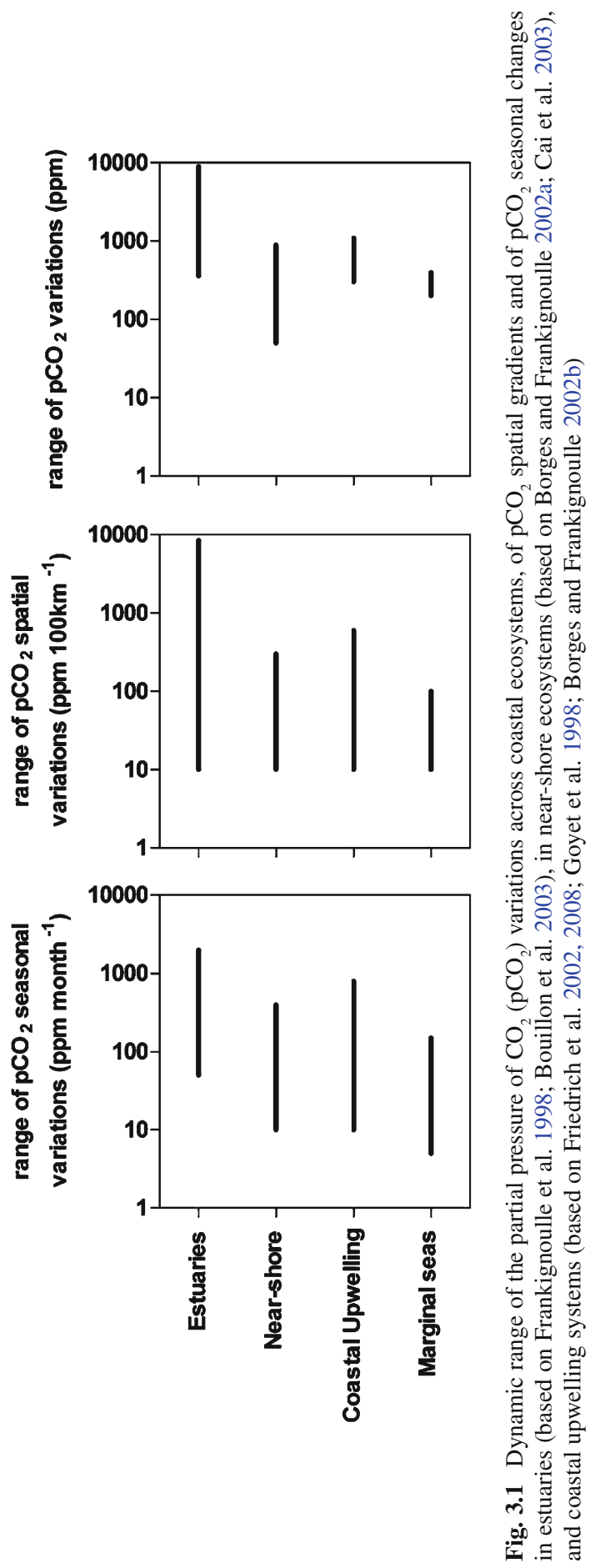


source of $\mathrm{CO}_{2}$ based on a data-set with a lower temporal coverage than the one of Schiettecatte et al. (2007) who reported a sink of atmospheric $\mathrm{CO}_{2}$. Another example is in the US South Atlantic Bight, where Cai et al. (2003) reported a source of $\mathrm{CO}_{2}$ based on a data-set with a lower spatial resolution than the one of Jiang et al. (2008a) who reported a sink of atmospheric $\mathrm{CO}_{2}$.

Inter-annual variations of air-sea $\mathrm{CO}_{2}$ fluxes in the coastal ocean can be significant although they have been seldom investigated due to the lack of adequate datasets. In continental shelf seas, these inter-annual variations can be due to large scale climate oscillations such as the El Niño Southern Oscillation (ENSO) (Ianson and Allen 2002; Friederich et al. 2002) or such as the Southern Annular Mode (SAM) (Borges et al. 2008a). In the case of the California current, the change of ENSO phases can lead to a reversal of the direction of annual air-sea $\mathrm{CO}_{2}$ fluxes (Friederich et al. 2002). In near-shore ecosystems, inter-annual variations of air-sea $\mathrm{CO}_{2}$ fluxes can be due to variable river influence (Borges and Frankignoulle 1999; Gypens et al. 2004; Borges et al. 2008b; Salisbury et al. 2009).

Contemporary air-sea $\mathrm{CO}_{2}$ fluxes deduced from field measurements of $\mathrm{pCO}_{2}$ are the combination of natural (pre-industrial) air-sea $\mathrm{CO}_{2}$ flux signal and a perturbation air-sea $\mathrm{CO}_{2}$ flux signal related to the anthropogenic increase of atmospheric $\mathrm{CO}_{2}$. The pre-industrial air-sea $\mathrm{CO}_{2}$ fluxes can be roughly evaluated by the mass balance of carbon inputs and outputs for the whole ocean (open and coastal) at global scale (e.g. Sarmiento and Sundquist 1992). In the open ocean, the inventory of anthropogenic dissolved inorganic carbon (DIC) can be evaluated by several back-calculation techniques (e.g. Vázquez-Rodríguez et al. 2009) that allow deriving a pre-formed DIC value that is removed from the observed DIC value, the difference corresponding to the anthropogenic DIC signal. The evaluation of a pre-formed DIC value relies on the analysis of chemical variables in water masses that are assumed to be devoid of anthropogenic DIC (deep waters). Due to the shallowness of the coastal ocean, it is impossible to evaluate preformed DIC values. Further, in the coastal ocean the anthropogenic air-sea $\mathrm{CO}_{2}$ flux signal is expected to be influenced by other perturbations besides the increase of atmospheric $\mathrm{CO}_{2}$, such as changes in nutrient inputs by atmospheric deposition or by rivers. The only attempts to evaluate the anthropogenic $\mathrm{CO}_{2}$ sink in the coastal ocean have been made with two modelling studies. Mackenzie et al. (2004) used a single box model of the coastal ocean and evaluated the sink of anthropogenic $\mathrm{CO}_{2}$ to $0.17 \mathrm{PgC}$ year $^{-1}$. Bopp et al. (2008) used a high resolution ocean model $\left(0.5^{\circ} \times 0.5^{\circ}\right)$ and evaluated the sink of anthropogenic $\mathrm{CO}_{2}$ in the coastal ocean to $0.13 \mathrm{PgC}_{\text {year }}{ }^{-1}$. Hence, the coastal ocean presently contributes between $6 \%$ and $11 \%$ of the sink of anthropogenic $\mathrm{CO}_{2}$ in the open ocean, ranging between 1.5 and 2.2 PgC year ${ }^{-1}$ (Sarmiento et al. 2000; Gloor et al. 2003; Quay et al. 2003; Gurney et al. 2004; Sabine et al. 2004; Patra et al. 2005; Gruber et al. 2009).

The proximal coastal ocean (estuaries, bays, salt-marshes, mangroves, and other near-shore ecosystems) is directly influenced by terrestrial inputs of DIC, nutrients and organic carbon. At ecosystem level, the aquatic compartment of these environments is net heterotrophic, consuming more organic carbon than the autochtonous gross primary production (GPP) (Odum and Hoskin 1958; Odum and Wilson 1962; 
Heip et al. 1995; Kemp et al. 1997; Gattuso et al. 1998a; Gazeau et al. 2004; Hopkinson and Smith 2005). Accordingly, the aquatic compartment of these ecosystems is a source of $\mathrm{CO}_{2}$ to the atmosphere (Frankignoulle et al. 1998, Borges et al. 2003; Abril and Borges 2004; Wang and Cai 2004). The contribution of $\mathrm{CO}_{2}$ inputs by rivers to the overall estuarine emission is generally low (Borges et al. 2006; Jiang et al. 2008b). The overall source of $\mathrm{CO}_{2}$ from near-shore ecosystems has been evaluated to $\sim 0.50 \mathrm{PgC}_{\text {year }}{ }^{-1}$, mainly related to the emission of $\mathrm{CO}_{2}$ to the atmosphere from estuaries ( 0.36 $\left.\mathrm{PgC} \mathrm{year}^{-1}\right)$ (e.g. Chen and Borges 2009). These estimations also suffer from the same caveats as those for continental shelf seas. Data distribution is biased towards the temperate regions of the Northern Hemisphere, and most estuaries where $\mathrm{CO}_{2}$ fluxes have been evaluated are macrotidal estuaries, while data in other types of estuarine environments (fjords, fjards, lagoons, micro-tidal estuaries,...) are scarce. Further, the dynamic range of $\mathrm{pCO}_{2}$ variations in estuaries is very marked (Fig. 3.1) and issues of adequate spatial and temporal coverage are even more critical. Also, there is a large uncertainty related to value of estuarine surface area used to scale the $\mathrm{CO}_{2}$ flux data as discussed by Abril and Borges (2004) and Borges (2005). Yet, the estimate of the emission of $\mathrm{CO}_{2}$ from estuaries based on the scaled $\mathrm{CO}_{2}$ flux data is in reasonable agreement with the estimate based on the input of river $\mathrm{CO}_{2}$ and the degradation during estuarine transit of particulate (POC) and dissolved organic carbon (DOC) as discussed by Abril and Borges (2004), Borges (2005) and Chen and Borges (2009).

\subsection{Possible Evolution and Feedbacks Under Global Change}

Figure 3.2 depicts a conceptual diagram of the different anthropogenic forcings on the coastal ocean that can modify the sources and sinks of carbon and ultimately provide a feedback on increasing atmospheric $\mathrm{CO}_{2}$. Hereafter, the impact of these forcings and potential associated feedbacks will be discussed in relation to air-sea $\mathrm{CO}_{2}$ fluxes in the coastal ocean, when documented, and roughly quantified, when possible (Table 3.2).

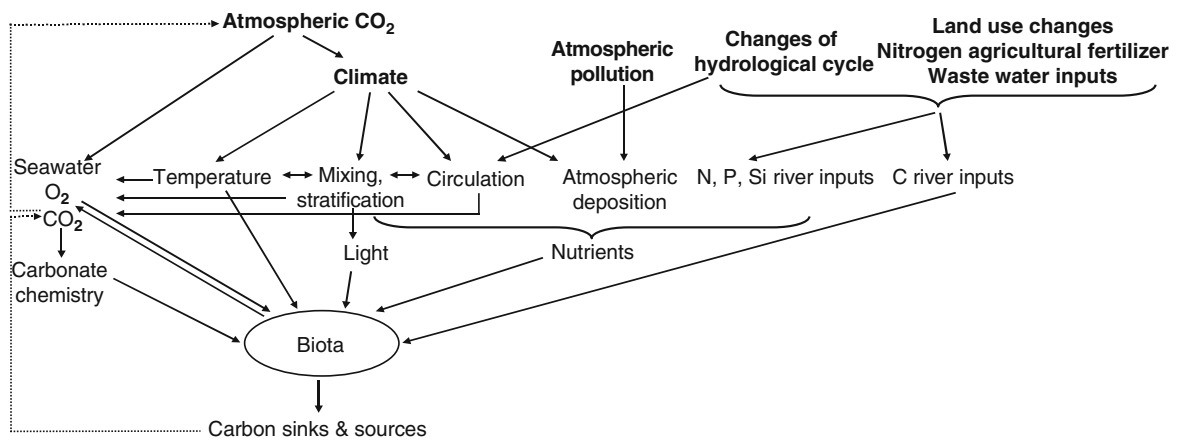

Fig. 3.2 Conceptual diagram of global change forcings on $\mathrm{C}$ cycling of the coastal ocean (bold), and feedbacks on increasing atmospheric $\mathrm{CO}_{2}$ (Adapated from Riebesell 2007) 
Table 3.2 Global change forcings on carbon cycling of the coastal ocean and associated feedback on increasing atmospheric $\mathrm{CO}_{2}$ by year 2100 . Refer to text for details on evaluation of sign and quantification of feedbacks

\begin{tabular}{llll}
\hline Global change forcings & Feedback & PgC year ${ }^{-1}$ & Comment \\
\hline Changes in coastal physics & & & \\
$\quad$ Enhanced stratification & $-?$ & $?$ & 1 \\
$\begin{array}{l}\text { Enhanced (?) coastal upwelling } \\
\text { Impact of expanding OMZ in coastal }\end{array}$ & $+?$ & $?$ & 2 \\
$\quad$ upwelling regions & + & $?$ & 3 \\
$\quad \begin{array}{l}\text { Enhancement of air-sea } \mathrm{CO}_{2} \text { fluxes related } \\
\quad \text { to Arctic sea-ice retreat }\end{array}$ & - & 0.002 & 4
\end{tabular}

Changes in land-used, waste water inputs, agricultural fertilizers and changes in hydrological cycle

Increase of river organic carbon delivery to + the Arctic Ocean

Increase of river nutrients delivery to the $\quad-\quad$ ? Arctic Ocean

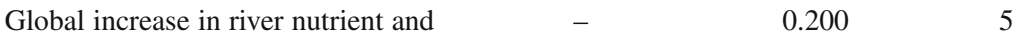
organic matter delivery

Global increase in nutrient atmospheric $\quad-\quad$ ? 6 deposition

Expanding hypoxic and anoxic zones

$+$

? 3

Changes in seawater carbonate chemistry (ocean acidification)

Decrease of benthic calcification

Coral reefs

Other benthic

$0.015-0.026$

environments

Decrease of pelagic calcification

Coccolithophorids

Other pelagic calcifiers

$-\quad 0.025-0.046$

Dissolution of metastable $\mathrm{CaCO}_{3}$ in sediment porewaters

Enhancement of primary production and export production due increasing $\left[\mathrm{CO}_{2}\right]$

1. Negative feedback only reported in Tasman shelf assuming $\mathrm{pCO}_{2}$ behaviour during warm years is representative of response to global warming, if extrapolated globally would produce a negative feed-back of the order of $\sim 0.1 \mathrm{PgC}$ year $^{-1}$.

2. Assuming exact opposite response of model output with decreasing upwelling favourable winds.

3. Assuming enhanced denitrification leading to decreased primary production.

4. Feedback computed for the next decade and not until 2100.

5. The enhancement of primary production by nutrient inputs balances the additional $\mathrm{CO}_{2}$ production by organic matter inputs.

6. Not taking into account enhancement of acidification of surface waters by sulphur atmospheric deposition.

7. Based on Andersson et al. (2003).

8. Based on a single mesocosm experiment with mixed diatom and coccolithophorid assemblage. 
Several changes in coastal ocean physics are expected with global warming that can change $\mathrm{C}$ cycling and air-sea $\mathrm{CO}_{2}$ fluxes, such as increasing stratification, enhanced coastal upwelling, expanding oxygen minimum zones, retreat of sea-ice and changes in freshwater delivery (Section 3.2.1).

Changes in land use, waste water inputs, agricultural fertilizers, hydrological cycle and atmospheric deposition increase the delivery of inorganic and organic carbon, and nutrients to the coastal ocean, and modify $\mathrm{C}$ flows (enhanced primary production and hypoxia/anoxia) and air-sea $\mathrm{CO}_{2}$ fluxes in the coastal ocean with potential feedbacks on increasing atmospheric $\mathrm{CO}_{2}$ (Section 3.2.2).

Changes in seawater carbonate chemistry in response to increasing atmospheric $\mathrm{CO}_{2}$ content can change the rates and fates of primary production and calcification at organism and ecosystem community levels, modifying $\mathrm{C}$ flows and air-sea $\mathrm{CO}_{2}$ fluxes in the coastal ocean with potential feedbacks on increasing atmospheric $\mathrm{CO}_{2}$ (Section 3.2.3).

Finally, anthropogenic impacts on specific near-shore coastal ecosystems (coral reefs, seagrass meadows and mangroves) can alter $\mathrm{C}$ flows in these ecosystems (Section 3.2.4).

\subsubsection{Changes in Coastal Ocean Physics}

It has been hypothesized (Bakun 1990) and modelled (Snyder et al. 2003; Diffenbaugh et al. 2004) that the intensity and duration of coastal upwelling will increase in future due to climate change. Increasing land-sea thermal contrasts will increase alongshore winds driving Ekman upwelling. Locally, other factors such as decadal fluctuations in surface heat fluxes can modulate the response to increasing upwelling favorable winds and lead to increased stratification and surface ocean warming, as evidenced in the California Current in relation to the Pacific Decadal Oscillation (Di Lorenzo et al. 2005; Field et al. 2006). Yet, there is observational evidence in several coastal upwelling systems that suggest a general increasing trend in upwelling with global warming (Anderson et al. 2002; Mendelssohn and Schwing 2002; Goes et al. 2005; Santos et al. 2005; McGregor et al. 2007).

The response of air-sea $\mathrm{CO}_{2}$ fluxes to increased upwelling is difficult to predict and can go both ways. Stronger vertical inputs of DIC would drive the system to emit more $\mathrm{CO}_{2}$ to the atmosphere, while enhanced nutrient inputs would drive higher primary production, export production and a sink for atmospheric $\mathrm{CO}_{2}$. Plattner et al. (2004) modelled the impact of decreasing upwelling favorable winds on $\mathrm{C}$ flows in the California Current system. Model results show that a $50 \%$ reduction of wind stress induces a $\sim 50 \%$ decrease in net primary production and in export production; yet, the source of $\mathrm{CO}_{2}$ to the atmosphere also decreases by about $\sim 50 \%$ due to the decrease of vertical inputs of DIC and the decrease of the gas transfer velocity, providing a negative feedback on increasing atmospheric $\mathrm{CO}_{2}$. However, the increase of upwelling favorable winds does not necessarily imply that the 
ecosystem will respond by an increase of primary production. Increased upwelling winds can also lead to a reduction of light exposure due to deeper mixed layers and to an increase offshore advection of phytoplankton (Largier et al. 2006). Nevertheless, a time series in Monterey Bay (California) shows since 1993 an increasing trend in $\mathrm{pCO}_{2}$ that is faster than the one expected from the equilibration with increasing atmospheric $\mathrm{CO}_{2}$, in parallel with a decreasing trend in sea surface temperature (SST) and an increasing trend in chlorophyll-a (Francisco Chavez and Gernot Friederich, 2009, personal communication). This would suggest an increasing trend in upwelling and primary production with an increase in $\mathrm{pCO}_{2}$ values, leading to an overall positive feedback on increasing atmospheric $\mathrm{CO}_{2}$.

Climate change is expected to lead to a decrease of oxygen $\left(\mathrm{O}_{2}\right)$ content in the oceans due to the slowing down of the thermohaline circulation and decreasing solubility of $\mathrm{O}_{2}$ (due to surface warming) of the source waters of intermediate and deep layers (Bopp et al. 2002; Matear and Hirst 2003). This will lead to the expansion of oxygen minimum zones (OMZ) as confirmed by historical observations (Bograd et al. 2008; Stramma et al. 2008). OMZ are associated to major coastal upwelling regions such as the Humbolt current, the Benguela current, the Canary current and the Arabian Sea. The upwelling source waters in coastal upwelling areas associated to $\mathrm{OMZ}$ are sources of $\mathrm{CO}_{2}$ to the atmosphere because denitrification leads to lower concentrations of nitrate and excess of DIC relative to nitrogen (Fig. 3.3). Hence, coastal upwelling areas associated to $\mathrm{OMZ}$ are sources of atmospheric $\mathrm{CO}_{2}$ such as the Arabian Sea (Goyet et al. 1998) and the Peruvian and Chilean coasts (Friederich et al. 2008; Paulmier et al. 2008). Coastal upwelling areas devoid of OMZ such as the Iberian coastal upwelling system (Borges and Frankignoulle 2002a) or with deep OMZ such as the Oregon coast (Hales et al. 2005) are sinks for atmospheric $\mathrm{CO}_{2}$. The future horizontal and vertical expansion of OMZ is then expected to provide a positive feedback on increasing atmospheric $\mathrm{CO}_{2}$ due to enhanced $\mathrm{CO}_{2}$ emissions from coastal upwelling systems.

Sarmiento et al. (1998) showed that future increase in stratification reduces the thermohaline circulation and open oceanic uptake of anthropogenic $\mathrm{CO}_{2}$. Yet, the ocean will also respond to increased stratification by changes in export production (Sarmiento et al. 1998; Bopp et al. 2001; Le Quéré et al. 2002, 2003) and in the vertical input of DIC, which potentially can provide feedbacks on increasing atmospheric $\mathrm{CO}_{2}$. The comparison of negative and positive SST anomaly phases of the large scale climatic oscillations (ENSO, SAM,...) can be used as a natural laboratory to determine how marine biogeochemistry could respond to future increase in SST and stratification in the oceans (Le Quéré et al. 2002, 2003). However, timeseries of $\mathrm{pCO}_{2}$ with the adequate temporal resolution and duration to work out seasonal and inter-annual variations are extremely scarce in continental shelf seas. Borges et al. (2008a) constructed a time-series of $\mathrm{pCO}_{2}$ and air-sea $\mathrm{CO}_{2}$ fluxes in the Tasman continental shelf based on the analysis of anomalies of $\mathrm{pCO}_{2}$ and SST from a data-set of 22 cruises spanning from 1991 to 2003. Over the Tasman continental shelf, during positive phases of SAM, there is a decrease of wind speed that leads to increasing SST and stratification (Fig. 3.4). The increase of stratification leads to a decrease of vertical inputs of DIC and overall decrease in $\mathrm{pCO}_{2}$ and 

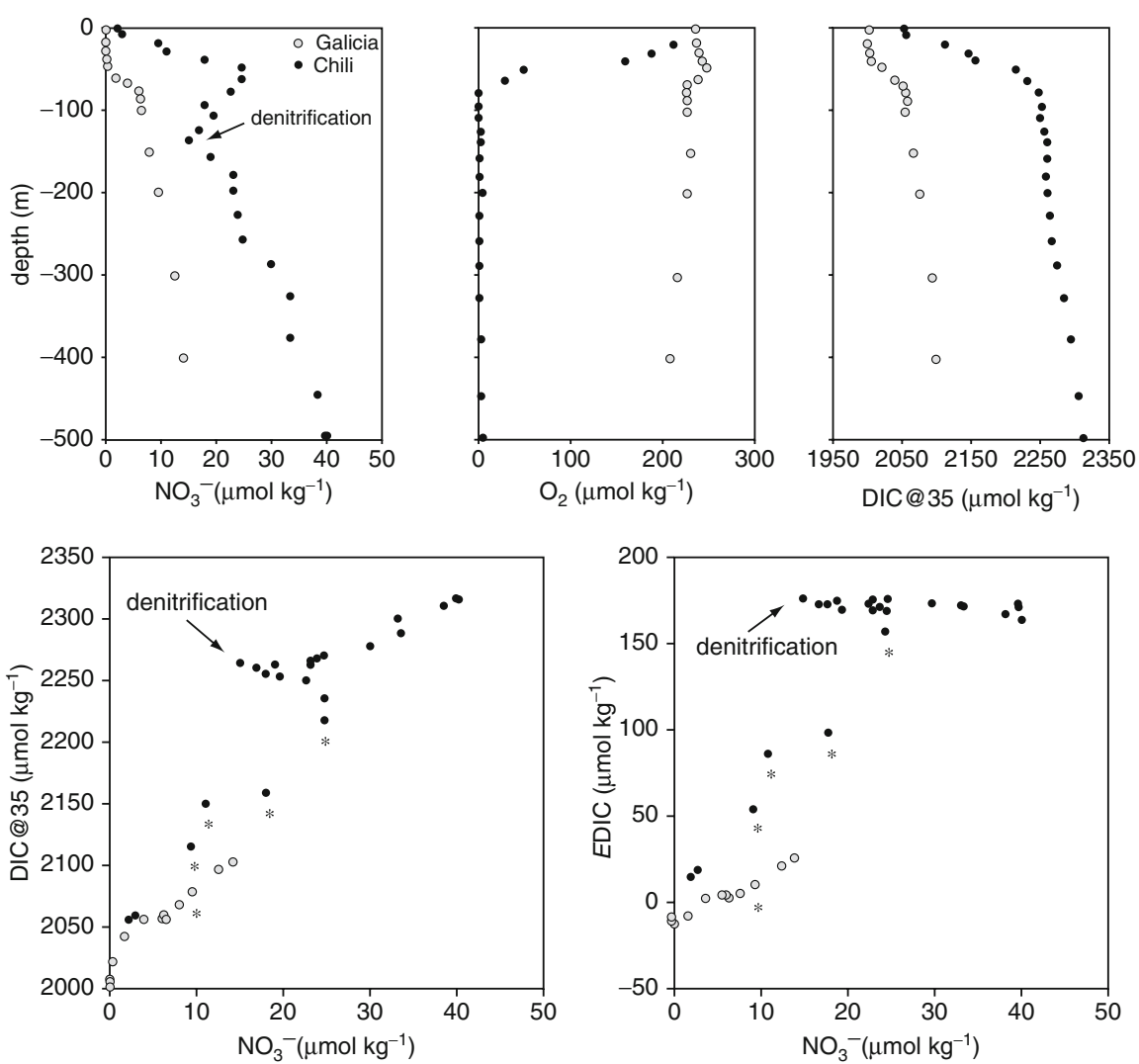

Fig. 3.3 Vertical profiles in the top $500 \mathrm{~m}$ of nitrate $\left(\mathrm{NO}_{3}^{-}\right)$, dissolved oxygen $\left(\mathrm{O}_{2}\right)$, dissolved inorganic carbon normalized to a salinity of 35 (DIC@35), DIC@35 vs $\mathrm{NO}_{3}^{-}$, excess DIC (EDIC) vs $\mathrm{NO}_{3}^{-}$at the continental shelf break of the Galician $\left(-9.54^{\circ} \mathrm{E} 42.15^{\circ} \mathrm{N}\right)$ and Chilean $\left(-77.59^{\circ} \mathrm{E}\right.$ $-12.45^{\circ} \mathrm{N}$ ) upwelling systems. Chilean data were extracted from the Global Ocean Data Analysis Project (Key et al. 2004), Galician data are from the OMEX-II project (Borges and Frankignoulle 2002a). EDIC was computed as the difference between observed DIC and DIC computed from total alkalinity and atmospheric $\mathrm{CO}_{2}$, and provides an estimate of $\mathrm{CO}_{2}$ outgassing if the water mass is upwelled. Asterisks indicate the depths from which water can be upwelled (10-50 $\mathrm{m}$ in the Chilean upwelling system based on Paulmier et al. (2008) and $200 \mathrm{~m}$ in the Galician upwelling system based on Borges and Frankignoulle (2002a)). For a given $\mathrm{NO}_{3}{ }^{-}$value (indicative of potential primary production), DIC@35 and EDIC (indicative of potential $\mathrm{CO}_{2}$ outgassing) are higher in the Chilean upwelling system than in the Galician upwelling, probably in relation to denitrification associated to the marked oxygen minimum zone in the Chilean upwelling system. This could explain that the Chilean upwelling system behaves as a source of $\mathrm{CO}_{2}$ (Friederich et al. 2008) and the Galician upwelling system as a sink of $\mathrm{CO}_{2}$ (Borges and Frankignoulle 2002a)

increase in the sink for atmospheric $\mathrm{CO}_{2}$ (Fig. 3.4). Hirst (1999) modelled an increase of SST at the latitude of the Tasman continental shelf of about $2^{\circ} \mathrm{C}$ by 2100. If we assume that the response of air-sea $\mathrm{CO}_{2}$ fluxes to inter-annual positive anomalies of SST are representative of the response of air-sea $\mathrm{CO}_{2}$ fluxes under global warming, this would lead to an enhancement of the sink of atmospheric $\mathrm{CO}_{2}$ 

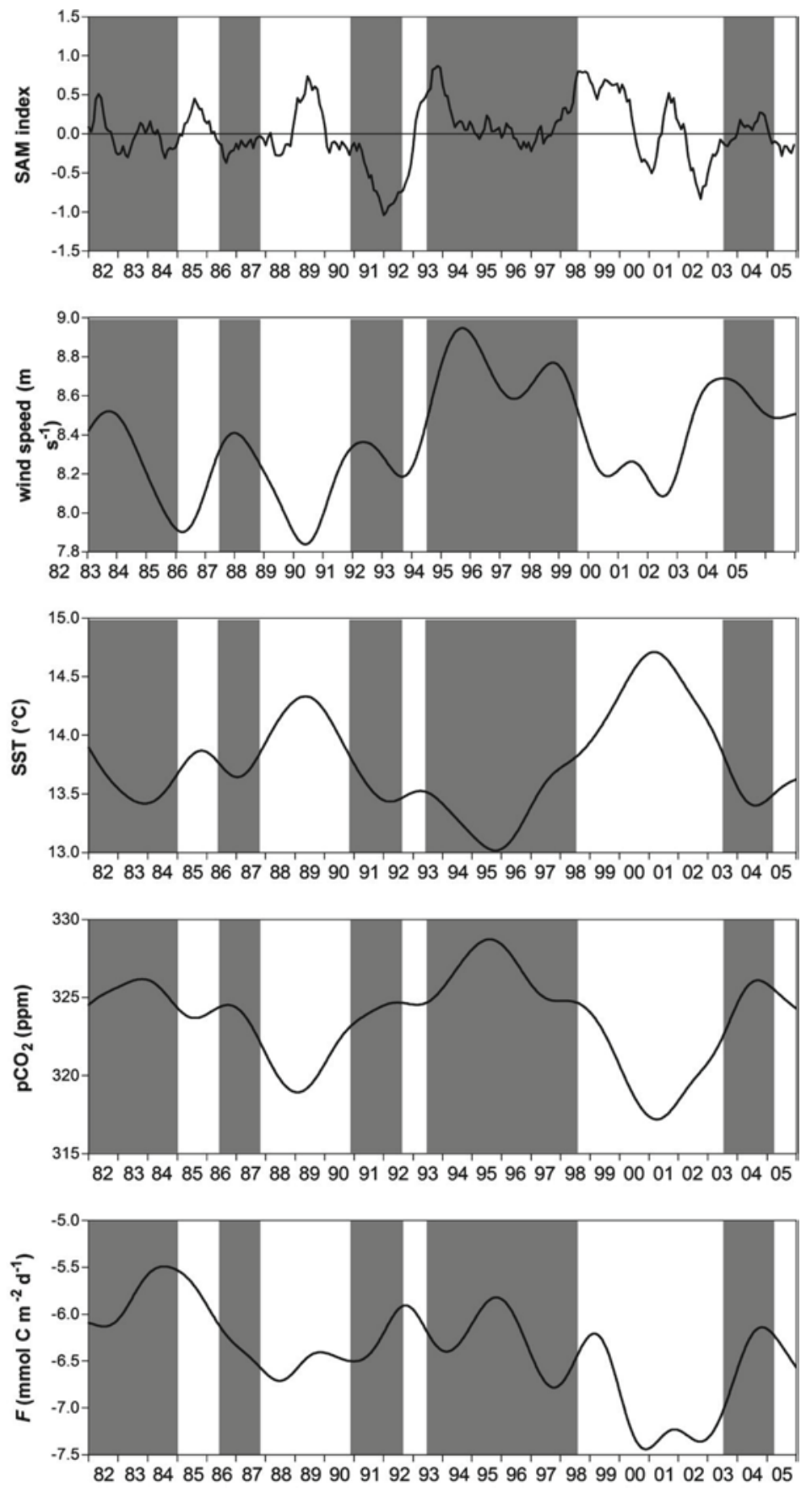

Fig. 3.4 Time-series from 1982 to 2005 of Southern Annular Mode (SAM) index and of deseasonalized sea surface temperature (SST), partial pressure of $\mathrm{CO}_{2}\left(\mathrm{pCO}_{2}\right)$ and air-sea $\mathrm{CO}_{2}$ fluxes $(\mathrm{F})$ in the Tasman continental shelf (adapted from Borges et al. 2008a). Grey areas correspond to periods of sustained negative SST anomalies 
in the Tasman continental shelf of about 36\%. Assuming all continental shelves respond similarly this would lead to a major feedback on increasing atmospheric $\mathrm{CO}_{2}$ from a present day sink of $0.3-0.4 \mathrm{PgC}_{\text {year }}^{-1}$ by 2100 . However, it is extremely unlikely that all continental shelves will respond by an increase in the sink of atmospheric $\mathrm{CO}_{2}$ with increasing stratification. More data acquisition and analysis are required to characterize the possible responses of air-sea $\mathrm{CO}_{2}$ fluxes to changes in stratification in continental shelf seas.

Climate changes will probably strongly affect $\mathrm{C}$ cycling and air-sea $\mathrm{CO}_{2}$ fluxes in the Arctic Ocean that at present time has been evaluated as a sink for atmospheric $\mathrm{CO}_{2}$ (Pipko et al. 2002; Murata and Takizawa 2003; Bates 2006; Bates et al. 2005; 2006; Else et al. 2008; Murata et al. 2008). Bates et al. (2006) found a positive relationship between air-sea $\mathrm{CO}_{2}$ fluxes and the ice-sea cover in the Chukchi Sea. Assuming that this relationship could be used to predict the evolution of air-sea $\mathrm{CO}_{2}$ fluxes with the future predicted sea-ice retreat, these authors estimated that the sink of atmospheric $\mathrm{CO}_{2}$ in the Arctic Ocean would increase in the coming decade by $0.002 \mathrm{PgC}_{\text {year }}{ }^{-1}$ compounded each year. However, it is also expected that future changes in temperature will modulate air-sea $\mathrm{CO}_{2}$ fluxes directly through the thermodynamic change of $\mathrm{pCO}_{2}$. Future changes in temperature will indirectly modulate air-sea $\mathrm{CO}_{2}$ fluxes through changes in circulation (combined with salinity changes due to sea-ice retreat and changes in fresh-water delivery) that will affect DIC transport (horizontally and vertically) and will also affect biological activity and $\mathrm{C}$ flows.

\subsubsection{Changes in Land Use, Waste Water Inputs, Agricultural Fertilizers, Hydrological Cycle and Atmospheric Deposition}

A major change in $\mathrm{C}$ flows and air-sea $\mathrm{CO}_{2}$ fluxes can be expected from the mobilization of terrestrial matter and transport by rivers to the Arctic Ocean. The Arctic Ocean receives almost $10 \%$ of global river discharge and about $0.025 \mathrm{PgC} \mathrm{year}^{-1}$ of terrestrial DOC (Opshal et al. 1999). Arctic river basins may store up to $~ 50 \%$ of the global soil organic carbon (Macdonald et al. 2006), with permafrost soils storing about $400 \mathrm{PgC}$ (Davidson and Janssens 2006). An increase of fresh water discharge to the Arctic during the last 60 years has been reported (Peterson et al. 2002) and could continue to increase in future (McClelland et al. 2004). This could enhance organic carbon delivery by rivers to the Arctic Ocean that could be further increased by mobilization of soil organic carbon with permafrost thawing (Frey and Smith 2005). The DOC delivered during ice-out is mostly young (Benner et al. 2004; Raymond et al. 2007) and labile (Holmes et al. 2008). Hence, the degradation of the additional organic carbon delivered by rivers to the Arctic Ocean with climate changes would provide a positive feedback on increasing atmospheric $\mathrm{CO}_{2}$ that could be significant but yet unquantified (Frey and McClelland 2009). On the other hand, the river delivery of dissolved inorganic nutrients (McClelland et al. 2007) and possibly dissolved organic nutrients (Frey and McClelland 2009) to the Arctic 
Ocean could also increase with climate change. This could stimulate primary production and provide a negative feedback on increasing atmospheric $\mathrm{CO}_{2}$ that could also be significant and is yet unquantified.

Changes in land use and waste water inputs have increased river nutrient contents (Green et al. 2004; Seitzinger et al. 2005) and are expected to continue to increase in future (Seitzinger et al. 2002; Galloway et al. 2004). The delivery of nutrients to the coastal ocean will also be modified by predicted future increasing global freshwater flow due to changes in the hydrological cycle (Douville et al. 2002; Labat et al. 2004; Milly et al. 2005; Aerts et al. 2006; Huntington 2006). However, future changes in freshwater flow will show regional differences, in general with an increase at high-latitudes and tropical latitudes and a decrease at mid-latitudes (Milly et al. 2005). The freshwater delivery to the coastal ocean will be further modulated by damming and other water diversion activities (Vörösmarty and Sahagian 2000; Vörösmarty et al. 2003).

It is established that nutrient delivery by rivers to the coastal ocean has increased during the past century and is expected to continue to increase in the future. This could lead to an enhancement of primary production and a negative feedback on increasing atmospheric $\mathrm{CO}_{2}$. On the other hand, increased organic matter river loadings are expected to fuel heterotrophic activity in the coastal ocean and provide a positive feedback on increasing atmospheric $\mathrm{CO}_{2}$. Yet, the balance between these two processes seems to be a negative feedback on increasing atmospheric $\mathrm{CO}_{2}$ due to the enhancement of net ecosystem production (NEP). Based on a simple one-box model of the coastal ocean, Mackenzie et al. (2004) have evaluated the negative feedback on increasing atmospheric $\mathrm{CO}_{2}$ by 2100 at $\sim 0.20 \mathrm{PgC}$ year $^{-1}$. Moreover, it has been recently reported that the impact of anthropogenic nitrogen atmospheric deposition on primary production has been under-estimated (Duce et al. 2008), hence the future increase in NEP and related negative feedback on increasing atmospheric $\mathrm{CO}_{2}$ could be stronger. Based on a coupled general circulation model, da Cunha et al. (2007) have shown that variable river inputs of nutrients have little impact on $\mathrm{C}$ cycling in the open ocean, hence, this impact seems to be confined to the coastal ocean. Gypens et al. (2009) have shown, based on a regional model, that nutrient reduction policies can lead to a strong decrease of primary production and NEP and a positive feedback increasing atmospheric $\mathrm{CO}_{2}$. However, at a global scale, the anthropogenic delivery of nutrients to the coastal zone and concomitant enhancement of NEP and sink of atmospheric $\mathrm{CO}_{2}$ is expected to continue to increase. The environmental policies actually implemented in watersheds of developed countries are not expected to be implemented for decades in emergent countries.

Changes in land use on watersheds and in freshwater flow can also alter the delivery of bicarbonate (and total alkalinity (TA)) from rivers to the coastal ocean (Cai 2003; Raymond and Cole 2003; Raymond et al. 2008; Cai et al. 2008; Gislason et al. 2009). This in itself constitutes a sink for atmospheric $\mathrm{CO}_{2}$ on the watershed if related to enhanced $\mathrm{CaCO}_{3}$ weathering. However, it is unclear how this could affect the coastal ocean $\mathrm{CO}_{2}$ sink, although an increase of the seawater buffering capacity can be expected. This will also be probably modulated by the changes in 
DIC:TA ratio in river water (Cai et al. 2008). Also, it has been suggested that TA generation in near-shore environments (Cai and Wang 1998) could contribute to enhance the seawater buffering capacity and enhance the sink for atmospheric $\mathrm{CO}_{2}$ in the coastal ocean (Fennel et al. 2008; Thomas et al. 2009).

An important consequence of eutrophication is the development of hypoxic or anoxic regions in coastal ecosystems (Diaz and Rosenberg 2008). In semienclosed seas permanently stratified, hypoxia is a perennial feature (Baltic Sea and Black Sea), while in seasonally stratified systems hypoxia is a seasonal feature, occurring usually in summer when temperature (and stratification) and organic matter availability are highest (Gulf of Mexico and East China Sea). In permanently well-mixed continental shelf seas, even highly eutrophicated such as the Southern Bight of the North Sea, hypoxia does not occur. However, in well-mixed (macro-tidal) estuaries, low oxygen levels and even hypoxia can occur mainly in maximum turbidity zones (e.g. Herman and Heip 1999), such as in the Scheldt estuary in the 1970s when eutrophication was highest (e.g. Soetaert et al. 2006). In estuaries, hypoxia can occur seasonally but also at daily time-scales (during the night) (Tyler et al. 2009). Hypoxia and anoxia have important consequences on benthic biomass and biodiversity with potential impacts on fisheries (Diaz and Rosenberg 2008). The impact on air-sea $\mathrm{CO}_{2}$ fluxes is difficult to evaluate, yet, by analogy with OMZ (Section 3.2.2) it is expected that the enhancement of denitrification at low oxygen levels will lead to a net $\mathrm{CO}_{2}$ production due to removal of nitrate and production of $\mathrm{CO}_{2}$. Denitrification will also increase TA and increase the buffering capacity of seawater and decrease the seawater $\mathrm{pCO}_{2}$ (Fennel et al. 2008; Thomas et al. 2009). This can lead to a negative feedback on increasing atmospheric $\mathrm{CO}_{2}$. Yet, the model of Fennel et al. (2008) in the northwest North Atlantic continental shelf shows that the contribution of TA generation by benthic denitrification to the enhancement of the $\mathrm{CO}_{2}$ sink $\left(0.07 \mathrm{mmolC} \mathrm{m}^{-2} \mathrm{year}^{-1}\right)$ is one order of magnitude lower than the decrease of the $\mathrm{CO}_{2}$ sink due to lower primary production related to the removal of nitrate $\left(0.17 \mathrm{mmolC} \mathrm{m}^{-2}\right.$ year $\left.^{-1}\right)$. Hence, the expansion of hypoxic or anoxic zones in coastal environments that has been observed since the 1960s (Diaz and Rosenberg 2008) and could increase in future with sustained eutrophication, can be expected to lead to a positive feedback on increasing atmospheric $\mathrm{CO}_{2}$ due to denitrification.

\subsubsection{Changes in Seawater Carbonate Chemistry}

Ocean acidification of surface waters corresponds to the increase of $\left[\mathrm{CO}_{2}\right]$ and of $\left[\mathrm{H}^{+}\right]$, the decrease of $\mathrm{pH}$, of $\left[\mathrm{CO}_{3}{ }^{2-}\right]$, and of the saturation state $(\Omega)$ of calcite $\left(\Omega_{\mathrm{ca}}\right)$ and aragonite $\left(\Omega_{\mathrm{ar}}\right)$, all related to shifts in thermodynamic equilibria in response to the input of anthropogenic $\mathrm{CO}_{2}$ from the atmosphere. The $\mathrm{CaCO}_{3}$ production of benthic and planktonic calcifiers is expected to decrease with decreasing $\Omega$ due to ocean acidification (refer to reviews by Raven et al. (2005), Kleypas et al. (2006), 
Fabry et al. (2008), Doney et al. (2009)). This is expected to provide a negative feedback on increasing atmospheric $\mathrm{CO}_{2}$ since calcification leads to a shift from the bicarbonate to the $\mathrm{CO}_{2}$ pool according to

$$
\mathrm{Ca}^{2+}+2 \mathrm{HCO}_{3}^{-} \rightarrow \mathrm{CaCO}_{3}+\mathrm{CO}_{2}+\mathrm{H}_{2} \mathrm{O}
$$

Furthermore, ocean acidification is expected to lead to an enhancement of shallowwater $\mathrm{CaCO}_{3}$ dissolution in the porewaters within sediments (Andersson et al. 2003), also providing a negative feedback on increasing atmospheric $\mathrm{CO}_{2}$.

On the other hand, primary production of some pelagic (e.g. Riebesell et al. 1993; Qiu and Gao 2002) and benthic (e.g. Gao et al. 1993; Zimmerman et al. 1997 ) non-calcifying autotrophs could increase with $\left[\mathrm{CO}_{2}\right]$. An increase in primary production associated to efficient organic carbon export would induce a negative feedback on increasing atmospheric $\mathrm{CO}_{2}$, according to

$$
\mathrm{CO}_{2}+\mathrm{H}_{2} \mathrm{O} \rightarrow \mathrm{CH}_{2} \mathrm{O}+\mathrm{O}_{2}
$$

Besides changes in primary production and calcification, marine organisms and communities can also respond to ocean acidification through changes in $\mathrm{N}_{2}$ fixation (e.g. Hutchins et al. 2007), shift in natural assemblages (e.g. Boyd and Doney 2002; Tortell et al. 2002; Engel et al. 2008) and an increase of export of organic matter to depth due to enhanced aggregation (e.g. Engel et al. 2004; Delille et al. 2005; Riebesell et al. 2007). All these processes could also provide a negative feedback on increasing atmospheric $\mathrm{CO}_{2}$.

Since the coastal ocean hosts a disproportionately more important biological activity than the open ocean, the potential feedbacks on increasing atmospheric $\mathrm{CO}_{2}$ related to the response of marine organisms and communities to the acidification of surface waters are expected to be disproportionately much more important in the coastal ocean than in the open ocean. Further, in coastal environments the acidification of surface waters could be enhanced compared to the open ocean due to anthropogenic atmospheric nitrogen and sulfur deposition (Doney et al. 2007), influence of river discharge (Gledhill et al. 2008; Salisbury et al. 2008) or related to upwelling of DIC rich waters (Feely et al. 2008).

During high-runoff, near-shore coastal environments influenced by estuaries can be exposed seasonally to low $\Omega$ values. Salisbury et al. (2008) showed that during highrunoff the plume of Kennebec river (Gulf of Maine) shows very low $\Omega$ values down to 0.4 associated to salinities down to 8 . However, most rivers show $\Omega$ values above 1 for salinities above 10 (Salisbury et al. 2008), hence, river plumes under-saturated in $\mathrm{CaCO}_{3}$ are not the common feature. Yet, in Arctic rivers $\Omega$ values are lower $(\Omega>1$ for salinities > 25). Hence, the increase of Arctic river runoff under global warming (Section 3.2.2) could lead to an extension of river plumes with low $\Omega$ values in the Arctic Ocean. However, river plumes are also typically eutrophicated, leading to an increase in primary production with an effect on carbonate chemistry (Gypens et al. 2009; Borges and Gypens 2010). Figure 3.5 shows the decadal changes of carbonate chemistry in the Southern North Sea. From the 1950s to the mid 1980s when GPP 


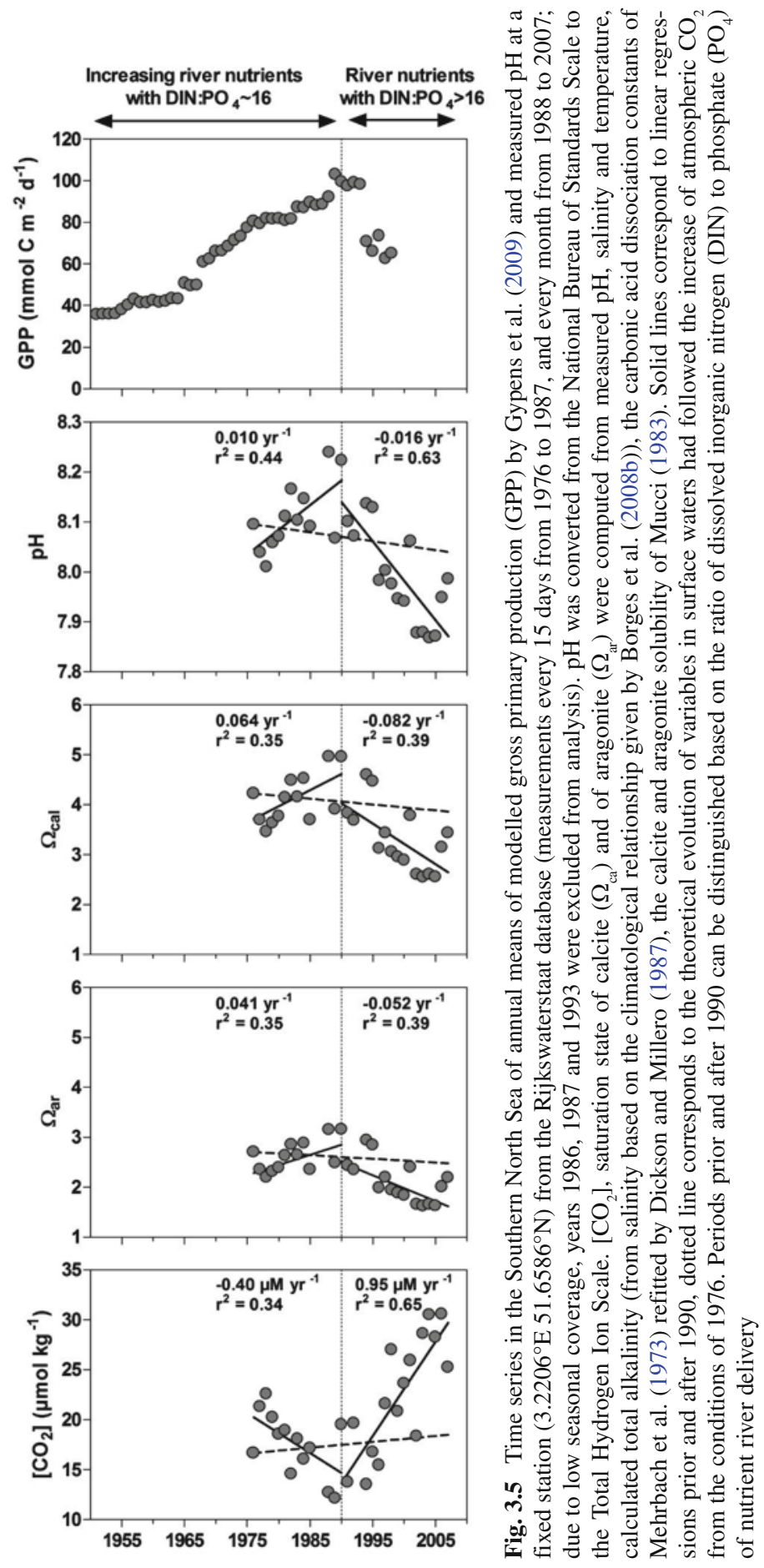


increased due to eutrophication, there is an increasing trend in $\mathrm{pH}$, in $\Omega_{\mathrm{ca}}$ and in $\Omega_{\mathrm{ar}}$ and a decreasing trend in $\left[\mathrm{CO}_{2}\right]$, while the equilibration of surface waters with increasing atmospheric $\mathrm{CO}_{2}$ would have lead to the opposite trends. After the mid 1980s when phosphorus removal policies were implemented, primary production in the Southern Bight of the North Sea became increasingly limited by phosphorus availability, GPP decreased and the ecosystem shifted from net autotrophy to net heterotrophy (Gypens et al. 2009). The decrease of $\mathrm{pH}, \Omega_{\mathrm{ca}}$ and $\Omega_{\mathrm{ar}}$ and the increase of $\left[\mathrm{CO}_{2}\right]$ were actually faster then those expected from the equilibration of surface waters with increasing atmospheric $\mathrm{CO}_{2}$ (Fig. 3.5). Hence, the effect of eutrophication on carbon cycling that counter-acts the effect of ocean acidification could maintain carbonate chemistry conditions that remain favorable for benthic and pelagic calcification in near-shore coastal environments. Also, the application of nutrient delivery regulation policies can lead to transient changes of carbonate chemistry that are faster than those related solely to ocean acidification. Such regulation policies have been mainly implemented in industrialized countries, while in emerging economy countries, eutrophication can be supposed to continue to increase unregulated in coming decades.

The response of calcifiers to ocean acidification has been to some extent relatively well documented. Based on the upper bound value global calcification rate from coral reefs of $0.11 \mathrm{PgC}_{\text {year }}{ }^{-1}$ (Milliman and Droxler 1996) and assuming a decrease by 2100 of calcification ranging from 22\% (Gattuso et al. 1998b) to 40\% (Andersson et al. 2005), and using a molar ratio of $\mathrm{CO}_{2}$ production to calcification $(\Psi)$ of 0.6 (Frankigoulle et al. 1994), the negative feedback on increasing atmospheric can be roughly evaluated to range between 0.015 and $0.026 \mathrm{PgC}_{\text {year }}{ }^{-1}$. Benthic calcification in other coastal environments than coral reefs has been evaluated to $0.19 \mathrm{PgC} \mathrm{year}^{-1}$ (Milliman and Droxler 1996), and assuming a similar range of decrease of calcification $(22-40 \%)$ by 2100 , the negative feedback on increasing atmospheric can be roughly evaluated to range between 0.025 and $0.046 \mathrm{PgC}_{\text {year }}{ }^{-1}$ (using a $\Psi$ of 0.6 ).

Balch et al. (2007) recently estimated global pelagic calcification to $1.6 \pm 0.3 \mathrm{Pg}$ $\mathrm{C}$ year ${ }^{-1}$, based on remote sensing data. This implies that coccolithophorids would be the single most important pelagic calcifier in the oceans, as other estimates of global pelagic calcification range between $0.7 \mathrm{PgC} \mathrm{year}^{-1}$ based on historical accumulation rates and sediment trap data (Milliman et al. 1999) and $1.4 \mathrm{PgC}_{\text {year }}{ }^{-1}$, based on seasonal cycle of TA in the euphotic zone (Lee 2001). A global estimate of pelagic calcification is unavailable for the coastal ocean, but on first approximation, it can be evaluated to $0.38 \pm 0.1 \mathrm{Pg} \mathrm{C}$ year ${ }^{-1}$ scaled based on a fraction of the total $\mathrm{CaCO}_{3}$ standing stock in the coastal ocean of $23 \%$ compared to the open ocean, based on remote sensing data (Balch et al. 2005). The decrease of global pelagic calcification for a doubling of atmospheric $\mathrm{CO}_{2}$ has been evaluated to $7 \%$ using a general circulation ocean model (Gehlen et al. 2007). If we assume that this decrease also occurs in the coastal ocean, the negative feedback on increasing atmospheric $\mathrm{CO}_{2}$ can be roughly evaluated to range between 0.013 and $0.019 \mathrm{PgC} \mathrm{year}^{-1}$ (using a $\Psi$ of 0.6).

The carboxylating enzyme Ribulose-1,5 bisphosphate-carboxylase/oxygenase (RUBISCO) relies exclusively on $\mathrm{CO}_{2}$ as substrate and has a half saturation constant ranging between 20 and $70 \mu \mathrm{mol} \mathrm{kg}{ }^{-1}$ (Badger et al. 1998). This can cause a rate limitation of phytoplankton photosynthesis, since $\left[\mathrm{CO}_{2}\right]$ in seawater at 
Table 3.3 Minimum values of the partial pressure of $\mathrm{CO}_{2}\left(\mathrm{pCO}_{2}\right), \mathrm{pH},\left[\mathrm{CO}_{2}\right]$ reported in various continental shelf seas

\begin{tabular}{lllcl}
\hline & $\mathrm{pCO}_{2}(\mathrm{ppm})$ & $\mathrm{pH}(\mathrm{THIS})$ & {$\left[\mathrm{CO}_{2}\right]\left(\mu \mathrm{mol} \mathrm{\textrm {kg } ^ { - 1 } )}\right.$} & Comment \\
\hline Gotland Sea (Baltic) & 160 & 8.413 & 6.2 & 1 \\
Northern North Sea & 225 & 8.261 & 10.9 & 2 \\
Southern North Sea & 125 & 8.459 & 5.7 & 2 \\
English Channel & 320 & 8.127 & 13.5 & 3 \\
Celtic Sea & 295 & 8.160 & 11.6 & 4 \\
Bay of Angels & 330 & 8.144 & 12.5 & 5 \\
$\quad$ Mediterranean) & & & & 6 \\
East China Sea & 280 & 8.173 & 12.3 & 7 \\
Chukchi Sea & 70 & 8.647 & 4.7 & 8 \\
US Middle Atlantic Bight & 200 & 8.285 & 6.1 &
\end{tabular}

1. Based on Schneider et al. (2003) and Kuss et al. (2004)

2. Based on Omar et al. (2010)

3. Based on Borges and Frankignoulle (2003)

4. Based on Borges et al. (2006)

5. Based on Copin-Montégut et al. (2004)

6. Based on Wang et al. (2000)

7. Based on Bates (2006)

8. Based on DeGrandpre et al. (2002)

atmospheric equilibrium is typically $\sim 10 \mu \mathrm{mol} \mathrm{kg} \mathrm{kg}^{-1}$. This can be a significant issue in near-shore environments where very low $\left[\mathrm{CO}_{2}\right]$ values can occur during the peak of the phytoplankton bloom. For instance, in Belgian coastal waters, at the peak of the Phaeocystis bloom extreme values of $\mathrm{pCO}_{2}(72 \mathrm{ppm}), \mathrm{pH}(8.673$ in the total hydrogen ion scale (THIS)) and [CO $]\left(3 \mu \mathrm{mol} \mathrm{kg} \mathrm{Cg}^{-1}\right)$ were reported in May 1999 (Borges and Frankignoulle 2002b). However, in continental shelf seas with lesser influence from nutrient rich estuarine waters, values of the variables of carbonate system during phytoplankton blooms are not as extreme (Table 3.3).

Phytoplankton species have developed several carbon concentration mechanisms (CCMs) to overcome the potential $\mathrm{CO}_{2}$ limitation of primary production (Raven 1991), leading to a specific sensitivity to $\mathrm{CO}_{2}$ availability. Hence, photosynthesis by diatoms and the prymnesiophyte Phaeocystis (Burkhardt et al. 1999, 2001; Rost et al. 2003) is at or close to $\mathrm{CO}_{2}$ saturation at typical actual marine $\mathrm{CO}_{2}$ levels. On the other hand, photosynthesis of coccolithophorids is well below $\mathrm{CO}_{2}$ saturation at typical actual marine $\mathrm{CO}_{2}$ levels (Rost et al. 2003). However, these findings are mainly based on laboratory cultures with optimal light and nutrient conditions. In the real ocean, at the peak of phytoplankton bloom, nutrients are exhausted, and since CCMs rely in one way or another on enzymes, low nitrogen availability can lead to a down-regulation of CCMs. Since $\mathrm{CO}_{2}$ levels are also low at the peak of the phytoplankton bloom, increasing levels of seawater $\mathrm{CO}_{2}$ with global change could reduce the limitation of photosynthesis by $\mathrm{CO}_{2}$ availability. In nutrient exhausted conditions, if light conditions remain favorable, phytoplankton continues to photosynthesize, and extracellular release of organic carbon allows regulation of the internal C:N:P ratios. This can lead to the formation of transparent 
exopolymer particles that have strong aggregative properties and can enhance organic carbon export from surface to depth (Engel et al. 2004). Hence, increasing $\mathrm{CO}_{2}$ levels with global change could lead to enhanced carbon export related to extracellular release of organic carbon in peak phytoplankton bloom conditions. Riebesell et al. (2007) have estimated that an increase of $27 \%$ of $\mathrm{C}$ export from mixed diatom and coccolithophorid assemblages would occur at an atmospheric $\mathrm{pCO}_{2}$ of $750 \mathrm{ppm}$. Based on the present day estimates of export production from the coastal ocean ranging from 0.4 (Wollast 1998) to $0.8 \mathrm{PgC} \mathrm{year}^{-1}$ (Chen 2004), the potential negative feedback on increasing atmospheric $\mathrm{CO}_{2}$ would range from 0.108 to $0.216 \mathrm{PgC}$ year $^{-1}$.

Ocean acidification can also lead to changes in phytoplankton composition (Boyd and Doney 2002; Tortell et al. 2002), with potential impacts on C cycling and export, and ultimately on air-sea $\mathrm{CO}_{2}$ fluxes. Further, the impact of ocean acidification will be modulated by the combined effect of other climate change impacts such as temperature increase and increased stratification. Temperature increase will directly impact metabolic rates of biota, while increased stratification will modulate vertical inputs of DIC and nutrients, and light conditions. The combined impact of temperature increase and acidification seems to lead to non-linear responses from phytoplankton (Feng et al. 2008). Temperature increase could also potentially modulate the response of coral reefs to ocean acidification (McNeil et al. 2004), although this has been strongly debated (Kleypas et al. 2005). Finally, increased stratification will favour phytoplankton communities that have a strong requirement for light availability and low inorganic nutrient requirements. Tyrrell and Merico (2004) reviewed the factors that favor the blooming of coccolithophorids and concluded that stratified and shallow mixed layers (inducing high light availability conditions) were one of the requisites for coccolithophorid blooming. Temperature increase and stratification could explain the appearance of not previously documented coccolithophorid blooms in some high latitude areas such as the Bering Sea (Merico et al. 2003) and the Barrents Sea (Smyth et al. 2004), the possible shift in the North Atlantic of phytoplankton communities towards coccolithophorids at the expense of diatoms based on the opal: $\mathrm{CaCO}_{3}$ ratio of sedimenting particles (Antia et al. 2001), and the trend since the 1950s towards increasing pelagic calcification based on mass of $\mathrm{CaCO}_{3}$ per coccolith from sediment cores (Iglesias-Rodriguez et al. 2008), in agreement with a global increase in stratification with strong impacts on marine productivity (Behrenfeld et al. 2006).

\subsubsection{Anthropogenic Impacts on Specific Near-Shore Coastal Ecosystems}

Specific near-shore coastal ecosystems are in most cases threatened by direct and indirect human impacts. For instance, losses in seagrass (Short and Neckles 1999; 
Duarte 2002) and coral reef ecosystems (Hughes et al. 2003) are observed and predicted to continue due to mechanical damage (dredging and anchoring), eutrophication and siltation, the latter two leading in particular to light limitation. Negative indirect human impacts on seagrass and coral ecosystems include increases of erosion by the rise of sea level, frequency and intensity of extreme weather events, ultraviolet irradiance and water temperature. Other coastal ecosystems such as mangrove forests or salt-marshes are relatively resilient to the present and future alteration of hydrology, pollution or global warming, but in some parts of the world they are being cleared for urban development and aquaculture (Alongi 2002). Furthermore, some coastal habitats are predicted to adapt and survive with shifts in species composition, as coral reef ecosystems (Hughes et al. 2003; Baker et al. 2004) but with probable loss of biodiversity and modifications of carbon flows. It is unclear how these changes will affect carbon flows and ultimately air-sea $\mathrm{CO}_{2}$ fluxes.

\subsection{Conclusions}

The present day contemporary $\mathrm{CO}_{2}$ fluxes in shelf seas could be significant for the global carbon cycle, since available estimates converge to a value of 0.3

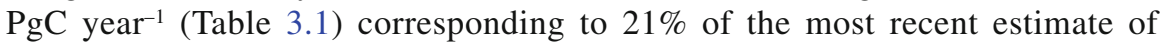
contemporary sink of atmospheric $\mathrm{CO}_{2}$ in open oceans of $1.4 \mathrm{PgC}_{\text {year }}{ }^{-1}$. However, these estimates are prone to large uncertainty, mainly due to inadequate representation of the spatial variability, and need to be improved based on more data, requiring a concerted global observational effort (Borges et al. 2009).

The potential feedbacks on increasing atmospheric $\mathrm{CO}_{2}$ from changes in carbon flows in the coastal ocean could be disproportionately higher than in the open ocean. Yet, these potential feedbacks remain largely unquantified (Table 3.2) due to a poor understanding of the mechanisms, or lack of modelling to quantify them. Based on reported evaluations and back of the envelope calculations, it is suggested that changes of biological activity due to the increased nutrient delivery by rivers would provide by 2100 a negative feedback on increasing atmospheric $\mathrm{CO}_{2}$ of the order of magnitude of the present day sink for atmospheric $\mathrm{CO}_{2}$. This negative feedback on increasing atmospheric $\mathrm{CO}_{2}$ would be one order of magnitude higher than negative feedback due to the decrease of either pelagic or benthic calcification related to ocean acidification, and than the negative feedback related to dissolution of $\mathrm{CaCO}_{3}$ in sediments (Table 3.2). The increase of export production could also provide a significant feedback to increasing atmospheric $\mathrm{CO}_{2}$, although based on the conclusions from a single perturbation experiment. Feedbacks on increasing atmospheric $\mathrm{CO}_{2}$ due to effects of $\mathrm{C}$ cycling in continental shelf seas related to changes in circulation or stratification could be important but remain to be quantified. 
Acknowledgments I'm grateful to Frédéric Gazeau for pointing out the availability of long $\mathrm{pH}$ time series in the Southern North Sea, to Nathalie Gypens for providing the GPP model outputs, and to Pedro Duarte for comments during manuscript elaboration. This is a contribution to Belgian Federal Science Policy Office PEACE project (SD/CS/03), EU IP CARBOOCEAN (511176), EU CSA COCOS (212196). The author is a research associate at the F.R.S.-F.N.R.S.

\section{References}

Abril G, Borges AV (2004) Carbon dioxide and methane emissions from estuaries. In: Tremblay A, Varfalvy L, Roehm C, Garneau M (eds) Greenhouse gases emissions from natural environments and hydroelectric reservoirs: Fluxes and processes. Springer, Berlin/Heidelberg, Germany/ New York, pp 187-207

Aerts JCJH, Renssen H, Ward PJ, de Moel H, Odada E, Bouwer LM, Goosse H (2006) Sensitivity of global river discharges under Holocene and future climate conditions. Geophys Res Lett 33:LI9401. doi:10.1029/2006GL027493

Alongi DM (2002) Present state and future of the world's mangrove forests. Environ Conserv 29(3):331-349

Anderson DM, Overpeck JT, Gupta AK (2002) Increase in the Asian southwest monsoon during the past four centuries. Science 297:596-599

Andersson AJ, Mackenzie FT, Ver LM (2003) Solution of shallow-water carbonates: An insignificant buffer against rising atmospheric $\mathrm{CO}_{2}$. Geology 31:513-516

Andersson AJ, Mackenzie FT, Lerman A (2005) Coastal ocean and carbonate systems in the high $\mathrm{CO} 2$ world of the Anthropocene. Am J Sc 305:875-918

Antia AN, Koeve W, Fischer G, Blanz T, Schulz-Bull D, Scholten J, Neuer S, Kremling K, Kuss J, Peinert R, Hebbeln D, Bathmann U, Conte M, Fehner U, ZeitzschelB (2001) Basin-wide particulate carbon flux in the Atlantic Ocean: Regional export patterns and potential for atmospheric CO2 sequestration. Global Biogeochem Cycles 15:845-862

Badger MR, Andrews TJ, Whitney SM, Ludwig M, Yellowlees CD, Leggat W, Price GD (1998) The diversity and coevolution of RUBISCO, plastids, pyrenoids, and chloroplastbased CO2-concentrating mechanisms in algae. Can J Bot 76:1052-1071

Baker AC, Starger CJ, McClanahan TR, Glynn PW (2004) Coral reefs: Corals' adaptive response to climate change. Nature 430(7001):741-741

Bakun A (1990) Global climate change and intensification of coastal ocean upwelling. Science 247(4939):198-201

Balch WM, Gordon HR, Bowler BC, Drapeau DT, Booth ES (2005) Calcium carbonate measurements in the surface global ocean based on Moderate-Resolution Imaging Spectroradiometer data. J Geophys Res 110:C07001. doi:10.1029/2004JC002560

Balch WM, Drapeau D, Bowler B, Booth E (2007) Prediction of pelagic calcification rates using satellite measurements. Deep Sea Res Part II 54:478-495

Bates NR (2006) Air-sea CO2 fluxes and the continental shelf pump of carbon in the Chukchi Sea adjacent to the Arctic Ocean. J Geophys Res 111:C10013. doi:10.1029/2005JC003083

Bates NR, Best MHP, Hansell DA (2005) Spatio-temporal distribution of dissolved inorganic carbon and net community production in the Chukchi and Beaufort Seas. Deep Sea Res II 52:3303-3323

Bates NR, Moran SB, Hansell DA, Mathis JT (2006) An increasing CO2 sink in the Arctic Ocean due to sea-ice loss. Geophys Res Lett 33:L23609. doi:10.1029/2006GL027028

Behrenfeld MJ, O'Malley RT, Siegel DA, McClain CR, Sarmiento JL, Feldman GC, Milligan AJ, Falkowski PG, Letelier RM, Boss ES (2006) Climate-driven trends in contemporary ocean productivity. Nature 444:752-755 
Benner R, Benitez-Nelson B, Kaiser K, Amon RMW (2004) Export of young terrigenous dissolved organic carbon from rivers to the Arctic Ocean. Geophys Res Lett 31:L05305. doi:10.1029/2003GL019251

Bograd SJ, Castro CG, Di Lorenzo E, Palacios DM, Bailey H, Gilly W, Chavez FP (2008) Oxygen declines and the shoaling of the hypoxic boundary in the California Current. Geophys Res Lett 35:L12607. doi:10.1029/2008GL034185

Bopp L, Monfray P, Aumont O, Dufresne JL, Le Treut H, Madec G, Terray L, Orr JC (2001) Potential impact of climate change on marine export production. Global Biogeochem Cycles 15(1):81-99

Bopp L, Le Quéré C, Heimann M, Manning AC, Monfray P (2002) Climate-induced oceanic oxygen fluxes: Implications for the contemporary carbon budget. Global Biogeochem Cycles 16(2):1022. doi:10.1029/2001GB001445

Bopp L, Borges AV, Aumont O, Ethe C, Ciais P (2008) Integrating CO2 fluxes in the coastal ocean: Simulating natural variability and anthropogenic uptake with a global model of $0.51 \frac{1}{2} \mathrm{~b} 0$ horizontal resolution, 2008 Ocean Sciences Meeting (ASLO AGU, TOS), March 2-7, 2008, Olando, FL

Borges AV (2005) Do we have enough pieces of the jigsaw to integrate CO2 fluxes in the Coastal Ocean ? Estuaries 28(1):3-27

Borges AV, Frankignoulle M (1999) Daily and seasonal variations of the partial pressure of $\mathrm{CO}_{2}$ in surface seawater along Belgian and southern Dutch coastal areas. J Mar Syst 19:251-266

Borges AV, Frankignoulle M (2002a) Distribution of surface carbon dioxide and air-sea exchange in the upwelling system off the Galician coast. Global Biogeochem Cycles 16(2):1020. doi:10.1029/2000GB001385

Borges AV, Frankignoulle M (2002b) Distribution and air-water exchange of carbon dioxide in the Scheldt plume off the Belgian coast. Biogeochemistry 59(1-2):41-67

Borges AV, Frankignoulle M (2003) Distribution of surface carbon dioxide and air-sea exchange in the English Channel and adjacent areas. J Geophys Res 108(C8):3140. doi:10.1029/2000JC000571

Borges AV, Djenidi S, Lacroix G, Théate J, Delille B, Frankignoulle M (2003) Atmospheric $\mathrm{CO}_{2}$ flux from mangrove surrounding waters. Geophys Res Lett 30(11):1558. doi:10.1029/2003GL017143

Borges AV, Delille B, Frankignoulle M (2005) Budgeting sinks and sources of $\mathrm{CO}_{2}$ in the coastal ocean: Diversity of ecosystems counts. Geophys Res Lett 32:L14601. doi:10.1029/2005GL023053

Borges AV, Schiettecatte L-S, Abril G, Delille B, Gazeau F (2006) Carbon dioxide in European coastal waters, Estuarine. Coast Shelf Sci 70(3):375-387

Borges AV, Tilbrook B, Metzl N, Lenton A, Delille B (2008a) Inter-annual variability of the carbon dioxide oceanic sink south of Tasmania. Biogeosciences 5:141-155

Borges AV, Ruddick K, Schiettecatte L-S, Delille B (2008b) Net ecosystem production and carbon dioxide fluxes in the Scheldt estuarine plume. BMC Ecology 8:15. doi:10.1186/1472-6785-8-15

Borges AV, Alin SR, Chavez FP, Vlahos P, Johnson KS, Holt JT, Balch WM, Bates N, Brainard R, Cai W-J, Chen CTA, Currie K, Dai M, Degrandpre M, Delille B, Dickson A, Feely RA, Friederich GE, Gong G-C, Hales B, Hardman-Mountford N, Hendee J, Hernandez-Ayon JM, Hood M, Huertas E, Hydes D, Ianson D (IOS, CA), Krasakopoulou E, Litt E, Luchetta A, Mathis J, McGillis WR, Murata A, Newton J, Ólafsson J, Omar A, Perez FF, Sabine C, Salisbury JE, Salm R, Sarma VVSS, Schneider B, Sigler M, Thomas H, Turk D, Vandemark D, Wanninkhof R, Ward B (2009) Global sea surface carbon observing system: Inorganic and organic carbon dynamics in coastal oceans. In: Hall J, Harrison DE, Stammer D (eds) Proceedings of OceanObs'09: Sustained ocean observations and information for society (vol 2), Venice, Italy, 21-25 September 2009. ESA Publication WPP-306

Borges A.V. \& N. Gypens (2010) Carbonate chemistry in the coastal zone responds more strongly to eutrophication than to ocean acidification, Limnology and Oceanography, 55, 346-353

Bouillon S, Frankignoulle M, Dehairs F, Velimirov B, Eiler A, Abril G, Etcheber H, Borges AV (2003) Inorganic and organic carbon biogeochemistry in the Gautami Godavari estuary (Andhra Pradesh, India) during pre-monsoon: The local impact of extensive mangrove forests. Global Biogeochem Cycles 17(No. 4):1114. doi:10.1029/2002GB002026

Boyd PW, Doney SC (2002) Modelling regional responses by marine pelagic ecosystems to global change. Geophys Res Lett 29. doi:10.1029/2001GL014130 
Burkhardt S, Zondervan I, Riebesell U (1999) Effect of CO2 concentration on the C:N:P ratio in marinephytoplankton: A species comparison. Limnol Oceanogr 44:683-690

Burkhardt S, Amoroso G, Riebesell U, Sültemeyer D (2001) CO2 and HCO3- uptake in marine diatomsacclimated to different CO2 concentrations. Limnol Oceanogr 46:1378-1391

Cai W-J (2003) Riverine inorganic carbon flux and rate of biological uptake in the Mississippi River plume. Geophys Res Lett 30(2):1032. doi:10.1029/2002GL016312

Cai W-J, Wang Y (1998) The chemistry, fluxes, and sources of carbon dioxide in the estuarine waters of the Satilla and Altamaha Rivers, Georgia. Limnol Oceanogr 43(4):657-668

Cai W-J, Wang ZA, Wang Y (2003) The role of marsh-dominated heterotrophic continental margins in transport of $\mathrm{CO} 2$ between the atmosphere, the land-sea interface and the ocean. Geophys Res Lett 30:1849. doi:10.1029/2003GL017633

Cai W-J, Dai MH, Wang YC (2006) Air-sea exchange of carbon dioxide in ocean margins: A province-based synthesis. Geophys Res Lett 33:L12603. doi:10.1029/2006GL026219

Cai W-J, Guo X, Chen CTA, Dai M, Zhang L, Zhai W, Lohrenz SE, Yin K, Harrison PJ, Wang Y (2008) A comparative overview of weathering intensity and $\mathrm{HCO}_{3}^{-}$flux in the world's major rivers with emphasis on the Changjiang, Huanghe, Zhujiang (Pearl) and Mississippi Rivers. Cont Shelf Res 28(1-2):1538-1549

Canadell JG, Le Quéré C, Raupach MR, Field CB, Buitenhuis ET, Ciais P, Conway TJ, Gillett NP, Houghton RA, Marland G (2007) Contributions to accelerating atmospheric $\mathrm{CO}_{2}$ growth from economic activity, carbon intensity, and efficiency of natural sinks. Proc Natl Acad Sci U S A 104:18353-18354

Chen CTA (2004) Exchange of carbon in the coastal seas. In: Field CB, Raupach MR (eds) The global carbon cycle: Integrating human, climate and the natural world. SCOPE, Washington, DC, pp 341-351

Chen CTA, Borges AV (2009) Reconciling opposing views on carbon cycling in the coastal ocean: Continental shelves as sinks and near-shore ecosystems as sources of atmospheric $\mathrm{CO}_{2}$. Deep Sea Res II 56(8-10):578-590

Copin-Montégut C, Bégovic M, Merlivat L (2004) Variability of the partial pressure of $\mathrm{CO}_{2}$ on diel to annual time scales in the Northwestern Mediterranean Sea. Mar Chem 85(3-4): 169-189

da Cunha LC, Buitenhuis ET, Le Quéré C, Giraud X, Ludwig W (2007) Potential impact of changes in river nutrient supply on global ocean biogeochemistry. Global Biogeochem Cycles 21:GB4007. doi:10.1029/2006GB002718

Davidson EA, Janssens IA (2006) Temperature sensitivity of soil carbon decomposition and feedbacks to climate change. Nature 440(7081):165-173

DeGrandpre MD, Olbu GJ, Beatty CM, Hammar TR (2002) Air-sea CO2 fluxes on the US Middle Atlantic Bight. Deep Sea Res Part II 49(20):4355-4367

Delille B, Harlay J, Zondervan I, Jacquet S, Chou L, Wollast R, Bellerby RGJ, Frankignoulle M, Borges AV, Riebesell U, Gattuso J-P (2005) Response of primary production and calcification to changes of pCO2 during experimental blooms of the coccolithophorid Emiliania huxleyi. Global Biogeochem Cycles 19:GB2023. doi:10.1029/2004GB002318

Diaz RJ, Rosenberg R (2008) Spreading dead zones and consequences for marine ecosystems. Science 321:926-929

Dickson AG, Millero FJ (1987) A comparison of the equilibrium constants for the dissociation of carbonic acid in seawater media. Deep Sea Res 34:1733-1743

Diffenbaugh NS, Snyder MA, Sloan LC (2004) Could $\mathrm{CO}_{2}$-induced land-cover feedbacks alter near-shore upwelling regimes? Proc Natl Acad Sci U S A 101(1):27-32

Di Lorenzo E, Miller AJ, Schneider N, McWilliams JC (2005) The Warming of the California current system: Dynamics and ecosystem implications. J Phys Oceanogr 35(3):336-362

Doney SC, Mahowald N, Lima I, Feely RA, Mackenzie FT, Lamarque J-F, Rasch PJ (2007) Impact of anthropogenic atmospheric nitrogen and sulfur deposition on ocean acidification and the inorganic carbon system. Proc Natl Acad Sci 104(37):14580-14585

Doney SC, Fabry VJ, Feely RA, Kleypas JA (2009) Ocean acidification: The other CO2 problem. Annu Rev Mar Sci 1:169-192 
Douville H, Chauvin F, Planton S, Royer JF, Salas-Melia D, Tyteca S (2002) Sensitivity of the hydrological cycle to increasing amounts of greenhouse gases and aerosols. Clim Dyn 20:45-68

Duarte CM (2002) The future of seagrass meadows. Environ Conserv 29(2):192-206

Duce RA, LaRoche J, Altieri K, Arrigo KR, Baker AR, Capone DG, Cornell S, Dentener F, Galloway J, Ganeshram RS, Geider RJ, Jickells T, Kuypers MM, Langlois R, Liss PS, Liu SM, Middelburg JJ, Moore CM, Nickovic S, Oschlies A, Pedersen T, Prospero J, Schlitzer R, Seitzinger S, Sorensen LL, Uematsu M, Ulloa O, Voss M, Ward B, Zamora L (2008) Impacts of atmospheric anthropogenic nitrogen on the open ocean. Science 320:893-997

Else BGT, Papakyriakou TN, Granskog MA, Yackel JJ (2008) Observations of sea surface fCO2 distributions and estimated air-sea $\mathrm{CO} 2$ fluxes in the Hudson Bay region (Canada) during the open-water season. J Geophys Res 113:C08026. doi:10.1029/2007JC004389

Engel A, Thoms U, Riebesell U, Rochelle-Newall E, Zondervan I (2004) Polysaccharide aggregation as a potential sink of marine dissolved organic carbon. Nature 428:929-932

Engel A, Schulz KG, Riebesell U, Bellerby R, Delille B, Schartau M (2008) Effects of CO2 on particle size distribution and phytoplankton abundance during a mesocosm bloom experiment (PeECE II). Biogeosciences 5:509-521

Fabry VJ, Seibel BA, Feely RA, Orr JC (2008) Impacts of ocean acidification on marine fauna and ecosystem processes. J Mar Sci 65:414-432

Feely RA, Sabine CL, Hernandez-Ayon JM, Ianson D, Hales B (2008) Evidence for upwelling of corrosive "acidified" water onto the continental shelf. Science 320:1490-1492

Feng Y, Warner ME, Zhang Y, Sun J, Fu FX, Rose JM, Hutchins DA (2008) Interactive effects of increased $\mathrm{pCO} 2$, temperature and irradiance on the marine coccolithophore Emiliania huxleyi (Prymnesiophyceae). Eur J Phycol 43(1):87-98

Fennel K, Wilkin J, Previdi M, Najjar R (2008) Denitrification effects on air-sea CO2 flux in the coastal ocean: Simulations for the northwest North Atlantic. Geophys Res Lett 35:L24608. doi:10.1029/2008GL036147

Field D Cayan, Chavez DF (2006) Secular warming in the California current and North Pacific, California cooperative oceanic fisheries investigations report 47: 92-110

Frankignoulle M, Borges AV (2001) European continental shelf as a significant sink for atmospheric carbon dioxide. Global Biogeochem Cycles 15(3):569-576

Frankignoulle M, Canon C, Gattuso JP (1994) Marine calcification as a source of carbon dioxide: Positive feedback of increasing atmospheric CO2. Limnol Oceanogr 39:458-462

Frankignoulle M, Abril G, Borges A, Bourge I, Canon C, Delille B, Libert E, Théate J-M (1998) Carbon dioxide emission from European estuaries. Science 282(5388):434-436

Frey KE, McClelland JW (2009) Impacts of permafrost degradation on arctic river biogeochemistry. Hydrol Process 23:169-182

Frey KE, Smith LC (2005) Amplified carbon release from vast West Siberian peatlands by 2100 . Geophys Res Lett 32:L09401. doi:10.1029/2004GL022025

Friederich GE, Walz PM, Burczynski MG, Chavez FP (2002) Inorganic carbon in the central California upwelling system during the 1997-1999 El Niño-La Niña event. Prog Oceanogr 54(1-4):185-203

Friederich GE, Ledesma J, Ulloa O, Chavez FP (2008) Air-sea carbon dioxide fluxes in the coastal southeastern tropical Pacific. Prog Oceanogr 79(2-4) 156-166

Galloway JN, Dentener FJ, Capone DG, Boyer EW, Howarth RW, Seitzinger SP, Asner GP, Cleveland CC, Green PA, Holland EA, Karl DM, Michaels AF, Porter JH, Townsend AR, Vörösmarty CJ (2004) Nitrogen cycles: Past, present, and future. Biogeochemistry 70:153-226

Gao K, Aruga Y, Asada K, Kiyohara M (1993) Influence of enhanced CO2 on growth and photosynthesis of the red algae Gracilaria sp and G-chilensis. J Appl Phycol 5:563-571

Gattuso J-P, Frankignoulle M, Wollast R (1998a) Carbon and carbonate metabolism in coastal aquatic ecosystems. Annu Rev Ecol Syst 29:405-433

Gattuso J-P, Frankignoulle M, Bourge I, Romaine S, Buddemeier B (1998b) Effect of calcium carbonate saturation of seawater on coral calcification. Glob Planet Change 18(1-2):37-46 
Gazeau F, Smith SV, Gentili B, Frankignoulle M, Gattuso J-P (2004) The European coastal zone: Characterization and first assessment of ecosystem metabolism. Estuar Coast Shelf Sci 60(4):673-694

Gehlen M, Gangst $\varnothing$ R, Schneider B, Bopp L, Aumont O, Ethe C (2007) The fate of pelagic CaCO3 production in a high CO2 ocean: A model study. Biogeosciences 4:505-519

Gislason SR, Oelkers EH, Eiriksdottir ES, Kardjilov MI, Gisladottir G, Sigfusson B, Snorrason A, Elefsen S, Hardardottir J, Torssander P, Oskarsson N (2009) Direct evidence of the feedback between climate and weathering. Earth Planet Sci Lett 277:213-222

Gledhill DK, Wanninkhof R, Millero FJ, Eakin M (2008) Ocean acidification of the Greater Caribbean Region 1996-2006. J Geophys Res 113:C10031. doi:10.1029/2007JC004629

Gloor M, Gruber N, Sarmiento J, Sabine CL, Feely RA, Rodenbeck C (2003) A first estimate of present and preindustrial air-sea $\mathrm{CO}_{2}$ flux patterns based on ocean interior carbon measurements and models. Geophys Res Lett 30. doi:10.1029/2002GL015594

Goes JI, Thoppil PG, do R Gomes H, Fasullo JT (2005) Warming of the Eurasian landmass is making the Arabian Sea more productive. Science 308(5721):545-547

Goyet C, Millero FJ, O'Sullivan DW, Eischeid G, McCue SJ, Bellerby RGJ (1998) Temporal variations of $\mathrm{pCO}_{2}$ in surface seawater of the Arabian sea in 1995. Deep Sea Res Part I 45(4-5):609-623

Green PA, Vörösmarty CJ, Meybeck M, Galloway JN, Peterson BJ, Boyer EW (2004) Preindustrial and contemporary fluxes of nitrogen through rivers: A global assessment based on typology. Biogeochemistry 68:71-105

Gruber N, Gloor M, Mikaloff Fletcher SE, Doney SC, Dutkiewicz S, Follows MJ, Gerber M, Jacobson AR, Joos F, Lindsay K, Menemenlis D, Mouchet A, Müller SA, Sarmiento JL, Takahashi $\mathrm{T}$ (2009) Oceanic sources, sinks, and transport of atmospheric $\mathrm{CO}_{2}$ Global Biogeochem Cycles 23:GB1005. doi:10.1029/2008GB003349

Gurney KR, Law RM, Denning AS, Rayner PJ, Pak B, the TransCom-3L2 modelers (2004) Transcom-3 inversion intercomparison: Control results for the estimation of seasonal carbon sources and sinks. Global Biogeocehm Cycles 18: GB1010. doi:10.1029/ 2003GB002111

Gypens N, Lancelot C, Borges AV (2004) Carbon dynamics and $\mathrm{CO}_{2}$ air-sea exchanges in the eutrophicated coastal waters of the Southern Bight of the North Sea: A modelling study. Biogeosciences 1(2):561-589

Gypens N, Borges AV, Lancelot C (2009) Effect of eutrophication on air-sea CO2 fluxes in the coastal Southern North Sea: A model study of the past 50 years. Glob Change Biol 15(4): $1040-1056$

Hales B, Takahashi T, Bandstra L (2005) Atmospheric CO2 uptake by a coastal upwelling system. Global Biogeochem Cycles 19:GB1009. doi:10.1029/2004GB002295

Heip C, Goosen NK, Herman PMJ, Kromkamp J, Middelburg JJ, Soetaert K (1995) Production and consumption of biological particles in temperate tidal estuaries. Oceanogr Mar Biol 33:1-149

Herman PMJ, Heip CHR (1999) Biogeochemistry of the MAximum TURbidity Zone of Estuaries (MATURE): Some conclusions. J Mar Syst 22:89-104

Hirst AC (1999) The Southern Ocean response to global warming in the CSIRO coupled oceanatmosphere model. Environ Modell Softw 14(4):227-241

Holmes RM, McClelland JW, Raymond PA, Frazer BB, Peterson BJ, Stieglitz M (2008) Lability of DOC transported by Alaskan rivers to the arctic ocean. Geophys Res Lett 35:L03402. doi:10.1029/2007GL032837

Hopkinson CSJ, Smith EM (2005) Estuarine respiration: An overview of benthic, pelagic and whole system respiration. In: del Giorgio PA, Williams PJL (eds) Respiration in aquatic ecosystems. Oxford University Press, Oxford, pp 123-147

Hughes TP, Baird AH, Bellwood DR, Card M, Connolly SR, Folke C, Grosberg R, HoeghGuldberg O, Jackson JBC, Kleypas J, Lough JM, Marshall P, Nystrom M, Palumbi SR, Pandolfi JM, Rosen B, Roughgarden J (2003) Climate change, human impacts, and the resilience of coral reefs. Science 301(5635):929-933

Huntington TG (2006) Evidence for intensification of the global water cycle: Review and synthesis. J Hydrol 319:83-95 
Hutchins DA, Fu FX, Zhang Y, Warner ME, Feng Y, Portune K, Bernhardt PW, Mulholland MR (2007) CO2 control of Trichodesmium N2 fixation, photosynthesis, growth rates, and elemental ratios: Implications for past, present, and future ocean biogeochemistry. Limnol Oceanogr 52(4):1293-1304

Ianson D, Allen SE (2002) A two-dimensional nitrogen and carbon flux model in a coastal upwelling region. Global Biogeochem Cycles 16(1):1011 doi:10.1029/2001GB001451

Iglesias-Rodriguez MD, Halloran PR, Rickaby REM, Hall IR, Colmenero-Hidalgo E, Gittins JR, Green DRH, Tyrrell T, Gibbs SJ, von Dassow P, Rehm E, Armbrust EV, Boessenkool KP (2008) Phytoplankton Calcification in a High-CO2 World. Science 320:336-340

IPCC (2007a) Climate change 2007: The physical science basis. Contribution of working group I to the fourth assessment report of the intergovernmental panel on climate change. In: Solomon S, Qin D, Manning M, Chen Z, Marquis M, Averyt KB, Tignor M, Miller HL (eds). Cambridge University Press, Cambridge, UK/New York, 996 pp

IPCC (2007b) Climate change 2007: Impacts, adaptation and vulnerability. Contribution of working group II to the fourth assessment report of the intergovernmental panel on climate change. In: Parry ML, Canziani OF, Palutikof JP, van der Linden PJ, Hanson CE (eds). Cambridge University Press, Cambridge 976 pp

Jahnke RA (2009) Global synthesis. In: Liu KK, Atkinson L, Quinones R, Talaue-McManus L (eds) (2010) Carbon and nutrient fluxes in continental margins: A global synthesis. Springer, New York

Jiang L-Q, Cai W-J, Wang Y (2008a) Carbon dioxide degassing in river- and marine-dominated estuaries: Importance of freshwater runoff. Limnol Oceanogr 53(6):2603-2615

Jiang L-Q, Cai W-J, Wanninkhof R, Wang Y, Hüger H (2008b) Air-sea CO2 fluxes on the US South Atlantic Bight: Spatial and seasonal variability. J Geophys Res 113:C07019, 17 pp. doi:10.1029/2007JC004366

Kemp WM, Smith EM, Marvin-DiPasquale M, Boynton WR (1997) Organic carbon-balance and net ecosystem metabolism in Chesapeake Bay. Mar Ecol Prog Ser 150:229-248

Key RM, Kozyr A, Sabine CL, Lee K, Wanninkhof R, Bullister JL, Feely RA, Millero FJ, Mordy C, Peng T-H (2004) A global ocean carbon climatology: Results from Global Data Analysis Project (GLODAP). Global Biogeochem Cycles 18:GB4031. doi:10.1029/2004GB002247

Kleypas JA, Buddemeier RW, Eakin CM, Gattuso J-P, Guinotte J, Hoegh-Guldberg O, IglesiasPrieto R, Jokiel PL, Langdon C, Skirving W, Strong AE (2005) Comment on "coral reef calcification and climate change: The effect of ocean warming". Geophys Res Lett 32:L08601. doi:10.1029/2004GL022329

Kleypas JA, Feely RA, Fabry VJ, Langdon C, Sabine CL, Robbins LL (2006) Impacts of ocean acidification on coral reefs and other marine calcifiers: A guide for future research, report of a workshop held 18-20 April 2005, St. Petersburg, FL, sponsored by NSF, NOAA, and the US Geological Survey, $88 \mathrm{pp}$

Kuss J, Nagel K, Schneider B (2004) Evidence from the Baltic Sea for an enhanced CO2 air-sea transfer velocity. Tellus Series B 56(2):175-182

Labat D, Godderis Y, Probst JL, Guyot JL (2004) Evidence for global runoff increase due to climate warming. Adv Water Resour 27:631-642

Largier JL, Lawrence CA, Roughan M, Kaplan DM, Dever EP, Dorman CE, Kudela RM, Bollens SM, Wilkerson FP, Dugdale RC, Botsford LW, Garfield N, Kuebel Cervantes B, Koračin D (2006) WEST: A northern California study of the role of wind-driven transport in the productivity of coastal plankton communities. Deep Sea Res II 53:2833-2849

Lee K-S (2001) Global net community production estimated from the annual cycle of surface water total dissolved inorganic carbon. Limnol Oceanogr 46:1287-1297

Le Quéré C, Bopp L, Tegen I (2002) Antarctic circumpolar wave impact on marine biology: A natural laboratory for climate change study. Geophys Res Lett 29(10):1407. doi: 10.1029/2001GL014585

Le Quéré C, Aumont O, Monfray P, Orr J (2003) Propagation of climatic events on ocean stratification, marine biology, and CO2: Case studies over the 1979-1999 period. J Geophys Res 108(C12):3375. doi:10.1029/2001JC000920 
MacDonald GM, Beilman DW, Kremenetski KV, Sheng YW, Smith LC, Velichko AA (2006) Rapid early development of circumarctic peatlands and atmospheric $\mathrm{CH} 4$ and $\mathrm{CO} 2$ variations. Science 314(5797):285-288

Mackenzie FT, Lerman A, Andersson AJ (2004) Past and present of sediment and carbon biogeochemical cycling models. Biogeosciences 1(1):11-32

Matear RJ, Hirst AC (2003) Long-term changes in dissolved oxygen concentrations in the ocean caused by protracted global warming. Global Biogeochem Cycles 17(4):1125. doi:10.1029/2002GB001997

McClelland JW, Holmes RM, Peterson BJ, Stieglitz M (2004) Increasing river discharge in the Eurasian Arctic: Consideration of dams, permafrost thaw, and fires as potential agents of change. J Geophys Res 109:D18102. doi:10.1029/2004JD004583

McClelland JW, Stieglitz M, Pan F, Holmes RM, Peterson BJ (2007) Recent changes in nitrate and dissolved organic carbon export from the upper Kuparuk River, North Slope, Alaska. J Geophys Res-Biogeosci 112:G04S60. doi:10.1029/2006JG000371

McGregor HV, Dima M, Fischer HW, Mulitza S (2007) Rapid 20th-century increase in coastal upwelling off Northwest Africa. Science 315:637-639

McNeil BI, Matear RJ, Barnes DJ (2004) Coral reef calcification and climate change: The effect of ocean warming. Geophys Res Lett 31:L22309. doi:10.1029/2004GL021541

Mehrbach C, Culberson CH, Hawley JE, Pytkowicz RM (1973) Measurement of the apparent dissociation constants of carbonic acid in seawater at atmospheric pressure. Limnol Oceanogr 18:897-907

Mendelssohn R, Schwing FB (2002) Common and uncommon trends in SST and wind stress in the California and Peru-Chile current systems. Prog Oceanogr 53:141-162

Merico A, Tyrrell T, Brown CW, Groom SB, Miller PI (2003) Analysis of satellite imagery for Emiliania huxleyi blooms in the Bering Sea before 1997. Geophys Res Lett 30:1337

Milliman JD, Droxler AW (1996) Neritic and pelagic carbonate sedimentation in the marine environment: Ignorance is not bliss. Geol Rundsh 85:496-504

Milliman JD, Troy PJ, Balch WM, Adams AK, Li YH, Mackenzie FT (1999) Biologically mediated dissolution of calcium carbonate above the chemical lysocline? Deep Sea Res Part I: Oceanogr Res Papers 46:1653-1669

Milly PCD Dunne KA, Vecchia AV (2005) Global patterns or trends in streamflow and water availability in a changing climate. Nature 438:347-350

Mucci A (1983) The solubility of calcite and aragonite in seawater at various salinities, temperatures, and one atmosphere total pressure. Am J Sci 283:781-799

Murata A (2006) Increased surface seawater pCO2 in the eastern Bering Sea shelf: An effect of blooms of coccolithophorid Emiliania huxleyi? Global Biogeochem Cycles 20:GB4006. doi:10.1029/2005GB002615

Murata A, Takizawa T (2003) Summertime CO2 sinks in shelf and slope waters of the western Arctic Ocean. Cont Shelf Res 23:753-776. 2003

Murata A, Shimada K, Nishino S, Itoh M (2008) Distributions of surface water CO2 and air-sea flux of $\mathrm{CO} 2$ in coastal regions of the Canadian Beaufort Sea in late summer. Biogeosci Discuss 5:5093-5132

Odum HT, Hoskin CM (1958) Comparative studies of the metabolism of Texas Bays. Publications of the Institute of Marine Science, University of Texas, vol 5, pp 16-46

Odum HT, Wilson R (1962) Further studies on the reaeration and metabolism of Texas Bays. Publications of the Institute of Marine Science, University of Texas, vol 8, pp 23-55

Omar AM, Olsen A, Johannessen T, Hoppema M, Thomas H, Borges AV (2010) Spatiotemporal variations of fCO2 in the North Sea. Ocean Sci 6:77-89

Opsahl S, Benner R, Amon RW (1999) Major flux of terrigenous dissolved organic matter through the Arctic Ocean. Limnol Oceanogr 44:2017-2023

Patra PK, Maksyutov S, Ishizawa M, Nakazawa T, Takahashi T, Ukita J (2005) Interannual and decadal changes in the sea-air $\mathrm{CO}_{2}$ flux from atmospheric $\mathrm{CO}_{2}$ inverse modeling. Global Biogeochem Cycles 19:GB4013. doi:10.1029/2004GB002257 
Paulmier A, Ruiz-Pino D, Garçon V (2008) The oxygen minimum zone (OMZ) off Chile as intense source of $\mathrm{CO}_{2}$ and $\mathrm{N}_{2} \mathrm{O}$. Cont Shelf Res 28:2746-2756

Peterson BJ, Holmes RM, McClelland JW, Vörösmarty CJ, Lammers RB, Shiklomanov AI, Shiklomanov IA, Rahmstorf S (2002) Increasing river discharge to the Arctic Ocean. Science 298:2171-2173

Pipko II, Semiletov IP, Tishchenko P, Ya Pugach SP, Christensen JP (2002) Carbonate chemistry dynamics in Bering Strait and the Chukchi Sea. Prog Oceanogr 55:77-94

Plattner G-K, Frenzel H, Gruber N, Leinweber A, McWilliams JC (2004) Changing winds and coastal carbon cycle: A case study for an upwelling region, The ocean in a high-CO2 world, 10-12 May 2004, Unesco, Paris, France

Qiu BS, Gao KS (2002) Effects of CO2 enrichment on the bloomforming cyanobacterium Microcystis aeruginosa (Cyanophyceae): Physiological responses and relationships with the availability of dissolved inorganic carbon. J Phycol 38:721-729

Quay P, Sommerup R, Westby T, Sutsman J, McNichol A (2003) Changes in the ${ }^{13} \mathrm{C} /{ }^{12} \mathrm{C}$ of dissolved inorganic carbon in the ocean as a tracer of anthropogenic $\mathrm{CO}_{2}$ uptake. Global Biogeochem Cycles 17:No. 1. doi:10.1029/2001GB001817

Raven J, Caldeira K, Elderfield H, Hoegh-Guldberg O, Liss P, Riebesell U, Shepherd J, Turley C, Watson A (2005) Ocean acidification due to increasing atmospheric carbon dioxide. The Royal Society, London

Raven JA (1991) Physiology of inorganic C acquisition and implications for resource use efficiency by marine phytoplankton: relation to increased $\mathrm{CO} 2$ and temperature. Plant Cell Environ 14:779-794

Raymond PA, Cole JJ (2003) Increase in the export of alkalinity from North America's largest river. Science 301(5629):88-91

Raymond PA, McClelland JW, Holmes RM, Zhulidov AV, Mull K, Peterson BJ, Striegl RG, Aiken GR, Gurtovaya TY (2007) Flux and age of dissolved organic carbon exported to the Arctic Ocean: A carbon isotopic study of the five largest arctic rivers. Global Biogeochem Cycles 21:GB4011. doi:10Đ1029/2007GB002934

Raymond PA, Oh NH, Turner RE, Broussard W (2008) Anthropogenically enhanced fluxes of water and carbon from the Mississippi River. Nature 451(7177):449-452

Riebesell U (2007) What are the maximum impacts of projected environmental changes on marine biology and the carbon cycle? Surface ocean $\mathrm{CO} 2$ variability and vulnerability workshop, IOC/UNESCO, Paris, France April 11-14

Riebesell U, Wolf-Gladrow DA, Smetacek V (1993) Carbon dioxide limitation of marine phytoplankton growth rates. Nature 361:249-251

Riebesell U, Schulz KG, Bellerby RGJ, Botros M, Fritsche P, Meyerhofer M, Neill C, Nondal G, Oschlies A, Wohlers J, Zollner E (2007) Enhanced biological carbon consumption in a high CO2 ocean. Nature 450:545-548

Rost B, Riebesell U, Burkhardt S, Sültemeyer D (2003) Carbon acquisition of bloom-forming marine phytoplankton. Limnol Oceanogr 48:55-67

Sabine CL, Feely RA, Gruber N, Key RM, Lee K, Bullister JL, Wanninkhof R, Wong CS, Wallace DWR, Tilbrook B, Peng T-H, Kozyr A, Ono T, Rios AF (2004) The oceanic sink for anthropogenic $\mathrm{CO}_{2}$. Science 305:367-371

Salisbury J, Green M, Hunt C, Campbell J (2008) Coastal acidification by rivers: A new threat to shellfish? Eos Trans AGU 89(50):513

Salisbury J, Vandemark D, Hunt C, Campbell J, Jonsson B, Mahadevan A, McGillis W, Xue H (2009) Episodic riverine influence on surface DIC in the coastal Gulf of Maine. Estuar Coast Shelf Sci 82:108-118

Santos AMP, Kazmin AS, Peliz A (2005) Decadal changes in the Canary upwelling system as revealed by satellite observations: Their impact on productivity. J Mar Res 63(2): 359-379

Sarmiento JL, Sundquist ET (1992) Revised budget for the oceanic uptake of Anthropogenic carbon dioxide. Nature 356:589-593 
Sarmiento JL, Hughes TMC, Stouffer RJ, Manabe S (1998) Simulated response of the ocean carbon cycle to anthropogenic climate warming. Nature 393(6682):245-249

Sarmiento JL, Monfray P, Maier-Reimer E, Aumont O, Murnane RJ, Orr JC (2000) Sea-air $\mathrm{CO}_{2}$ fluxes and carbon transport: A comparison of three ocean general circulation models. Global Biogeochem Cycles 14:1267-1281

Schiettecatte L-S, Thomas H, Bozec Y, Borges AV (2007) High temporal coverage of carbon dioxide measurements in the Southern Bight of the North Sea. Mar Chem 106(1-2): $161-173$

Schneider B, Nausch G, Nagel K, Wasmund N (2003) The surface water CO2 budget for the Baltic Proper: A new way to determine nitrogen fixation. J Mar Syst 42(1-2):53-64

Seitzinger SP, Kroeze C, Bouwman AF, Caraco N, Dentener F, Styles RV (2002) Global patterns of dissolved inorganic and particulate nitrogen inputs to coastal systems: Recent conditions and future projections. Estuaries 25(4b):640-655

Seitzinger SP, Harrison JA, Dumont E, Beusen AHW, Bouwman AF (2005) Sources and delivery of carbon, nitrogen, and phosphorus to the coastal zone: An overview of Global Nutrient Export from Watersheds (NEWS) models and their application. Global Biogeochem Cycles 19:GB4S01. doi:10.1029/2005GB002606

Short FT, Neckles HA (1999) The effects of global climate change on seagrasses. Aquat Bot 63(3-4):169-196

Smyth TJ, Tyrrell T, Tarrant B (2004) Time series of coccolithophore activity in the Barents Sea, from twenty years of satellite imagery. Geophys Res Lett 31:L11302. doi:10.1029/2004GL019735

Snyder MA, Sloan LC, Diffenbaugh NS, Bell JL (2003) Future climate change and upwelling in the California Current. Geophys Res Lett 30(15):1823. doi:10.1029/2003GL017647

Soetaert K, Middelburg JJ, Heip C, Meire P, Van Damme S, Maris T (2006) Long-term change in dissolved inorganic nutrients in the heterotrophic Scheldt estuary (Belgium, The Netherlands). Limnol Oceanogr 51(1):409-423

Stramma L, Johnson GC, Sprintall J, Mohrholz V (2008) Expanding oxygen-minimum zones in the tropical oceans. Science 320:655-658

Takahashi T, Sutherland SC, Wanninkhof R, Sweeney C, Feely RA, Chipman DW, Hales B, Friederich G, Chavez F, Sabine C, Watson A, Bakker DCE, Schuster U, Metzl N, YoshikawaInoue Hi, Ishii M, Midorikawa T, Nojiri Y, Körtzinger A, Steinhoff T, Hoppema M, Olafsson J, Arnarson TS, Tilbrook B, Johannessen T, Olsen A, Bellerby R, Wong CS, Delille B, Bates NR, de Baar HJW (2009) Climatological mean and decadal change in surface ocean pCO2, and net sea-air CO2 flux over the global oceans. Deep Sea Res II 56(8-10):554-577

Thomas H, Bozec Y, Elkalay K, De Baar HJW (2004) Enhanced open ocean storage of $\mathrm{CO}_{2}$ from shelf sea pumping. Science 304(5673):1005-1008

Thomas H, Schiettecatte L-S, Suykens K, Koné YJM, Shadwick EH, Prowe AEF, Bozec Y, de Baar HJW, Borges AV (2009) Enhanced ocean carbon storage from anaerobic alkalinity generation in coastal sediments. Biogeosciences 6:1-8

Tortell PD, DiTullio GR, Sigman DM, Morel FMM (2002) CO2 effects on taxonomic composition and nutrient utilization in an Equatorial Pacific phytoplankton assemblage. Mar Ecol-Prog Ser 236:37-43

Tsunogai S, Watanabe S, Sato T (1999) Is there a "continental shelf pump" for the absorption of atmospheric CO2? Tellus Ser B 51(3):701-712

Tyler RM, Brady DC, Targett TE (2009) Temporal and spatial dynamics of diel-cycling hypoxia in estuarine tributaries. Estuar Coast 32:123-145

Tyrrell T, Merico A (2004) Emiliania huxleyi: Bloom observations and the conditions that induce them in Coccolithophores. In: Thierstein HR, Young JR (eds) From molecular processes to global impact. Springer, Berlin, pp 75-97

Vázquez-Rodríguez M, Touratier F, Lo Monaco C, Waugh DW, Padin XA, Bellerby RGJ, Goyet C, Metzl N, Ríos AF, Pérez FF (2009) Anthropogenic carbon distributions in the Atlantic Ocean: Data-based estimates from the Arctic to the Antarctic. Biogeosciences 6:439-451 
Vörösmarty CJ, Sahagian D (2000) Anthropogenic disturbance of the terrestrial water cycle. BioScience 50(9):753-765

Vörösmarty CJ, Meybeck M, Fekete B, Sharma K, Green P, Syvitski JPM (2003) Anthropogenic sediment retention: Major global impact from registered river impoundments. Glob Planet Change 39(1-2):169-190

Walsh JJ (1988) On the nature of continental shelves. Academic, San Diego, CA/New York/ Berkeley CA/Boston, MA/London/Sydney/Tokyo/Toronto

Wang SL, Chen CTA, Hong G-H, Chung CS (2000) Carbon dioxide and related parameters in the East China Sea. Cont Shelf Res 20(4-5):525-544

Wang ZA, Cai W-J (2004) Carbon dioxide degassing and inorganic carbon export from a marshdominated estuary (the Duplin River): A marsh $\mathrm{CO}_{2}$ pump. Limnol Oceanogr 49(2):341-354

Wollast R (1998) Evaluation and comparison of the global carbon cycle in the coastal zone and in the open ocean. In: Brink KH, Robinson AR (eds) The global coastal ocean. Wiley, New York, pp 213-252

Zimmerman RC, Kohrs DG, Steller DL, Alberte RS (1997) Impacts of CO2 enrichment on productivity and light requirements of eelgrass. Plant Physiol 115:599-607 